\title{
Medievalista
}

Online

$26 \mid 2019$

Número 26

\section{Twelfth and early thirteenth century polychromy at the northernmost edge of Europe: past analyses and future research}

Policromia nos séculos XII e início de XIII no extremo norte da Europa: análises passadas e pesquisa futura

Kaja Kollandsrud and Unn Plahter

\section{OpenEdition}

\section{Journals}

\section{Electronic version}

URL: http://journals.openedition.org/medievalista/2303

DOI: $10.4000 /$ medievalista.2303

ISSN: $1646-740 X$

Publisher

Instituto de Estudos Medievais - FCSH-UNL

\section{Printed version}

Date of publication: 1 June 2019

\section{Electronic reference}

Kaja Kollandsrud and Unn Plahter, «Twelfth and early thirteenth century polychromy at the northernmost edge of Europe: past analyses and future research », Medievalista [Online], 26 | 2019, Online since 27 July 2019, connection on 18 October 2019. URL : http://journals.openedition.org/ medievalista/2303 ; DOI : 10.4000/medievalista.2303 
Título / Title: Twelfth and early thirteenth century polychromy at the northernmost edge of Europe: past analyses and future research / Policromia nos séculos XII e início de XIII no extremo norte da Europa: análises passadas e pesquisa futura

Autor(es) / Author(s): Kaja Kollandsrud (a, b); Unn Plahter (b)

Afiliação institucional (Unidade de Investigação, Faculdade ou Departamento, Universidade, Código postal, Cidade, País) / Institutional Affiliation (Research Center, Faculty or Department, University, Postcode, City, Country): (a) Museum of Cultural History 0164, Oslo Norway;

(b) University of Oslo, 0315, Oslo, Norway

Email Institucional / Institutional email: kaja.kollandsrud@khm.uio.no / unnp@extern.uio.no Fonte: Medievalista [Em linha]. Direc. Bernardo Vasconcelos e Sousa. Lisboa: IEM.

Disponível em: http://www2.fcsh.unl.pt/iem/medievalista/MEDIEVALISTA26/

Kollandsrud-plahter2605.html

ISSN: 1646-740X

DOI: $10.4000 /$ medievalista.2303

Data recepção do artigo / Received for publication: 20 de novembro de 2018

Data aceitação do artigo / Accepted in revised form: 29 de abril de 2019 


\section{Abstract}

The paper focuses on medieval wooden sculptures in the $12^{\text {th }}$ and early $13^{\text {th }}$ century in Norway, with preserved original polychromy. The presentation of materials used in the construction, the painting and gilding are based on material analyses. Their application is discussed and compared to those produced in the period that immediately follows. Conclusions reached about the characteristics of this period allow future research to be suggested. It is clear from the evidence gained that both the making and the perception of Catholic church art in medieval Norway was firmly rooted in an established culture consistent with Christian paradigms found in the rest of medieval Europe. The analytical results from the examination of sculpture preserved in Norway are therefore relevant to a wider European context. To what extent medieval sculpture was imported or produced in Norway and by whom is an ongoing discussion. A better knowledge of the sculptural traditions of a wider geographical area will provide the context required to improve our understanding of the cultural exchanges of the medieval period.

Keywords: Polychromy, Sculpture, Materiality, Painting technology, Medieval.

\section{Resumo}

O artigo foca-se em esculturas medievais de madeira dos séculos XII e XIII na Noruega, com policromia original preservada. A apresentação de materiais usados na construção, na pintura e na douradura baseiam-se na análise de materiais. A sua aplicação é discutida e comparada com casos do período imediatamente a seguir. As conclusões alcançadas relativamente às características deste período permitem a sugestão de investigação futura. Fica claro, a partir das evidências obtidas, que tanto a forma de fazer como a forma de percepcionar a arte da Igreja Católica na Noruega medieval estava firmemente enraizada numa cultura estabelecida que era consistente com os paradigmas cristãos encontrados no resto da Europa medieval. Os resultados analíticos do exame da escultura preservada na Noruega são, portanto, relevantes para um contexto europeu mais vasto. Até que ponto a escultura medieval foi importada para ou 
produzida na Noruega e por quem é uma discussão em aberto. Conhecer melhor as tradições escultóricas de uma área geográfica mais abrangente providenciará o contexto necessário para aperfeiçoarmos o entendimento que temos das trocas culturais do período medieval.

Palavras-chave: Policromia, Escultura, Materialidade, Tecnologia de pintura, Medieval. 


\title{
Twelfth and early thirteenth century polychromy at the northernmost edge of Europe: past analyses and future research / Policromia nos séculos XII e início de XIII no extremo norte da Europa: análises passadas e pesquisa futura
}

\author{
Kaja Kollandsrud and Unn Plahter
}

\section{Introduction}

In the Middle Ages, it is clear that people, and with them, their ideas, knowledge, craftsmanship, artistic styles and traded materials travelled along the networks of Europe. The results of these cultural exchanges are evident in the objects that are preserved, but the greater picture of how these intimate cultural exchanges occurred in the production of Christian art is yet to be drawn. The medieval sculpture preserved in Norway includes objects thought to be of Norwegian manufacture, as well as imported works. The physical objects are our most important source material, as written evidence describing the commissioning and production of these objects is scarce.

This article will point out the work that has already been done in order to disseminate the published scholarship on the material preserved in Norway. The situation in Norway is rather similar to that in neighbouring Sweden, whose inheritance of medieval sculpture is likewise highly relevant in the discussion of the mechanisms of cultural influence in the north ${ }^{1}$. It focusses on the polychrome sculpture that pre-dates the mid$13^{\text {th }}$ century; which shows a period marked by transition in the materiality and the painterly expression around 1225. The term materiality accords with James Elkin's definition, as elements of the "'purely' and 'merely' physical or material... to making,

1 TÅNGEBERG, Peter - Holzskulptur und Altarschrein. Studien zu Form, Material und Technik Mittelalterliche Plastik in Schweden. München: Georg D. W. Callwey, 1989.

Medievalista № 26 | Julho - Dezembro 2019 ๑ IEM - Instituto de Estudos Medievais 4 www2.fcsh.unl.pt/iem/medievalista 
the realm of art production" and the visual result ${ }^{2}$. Researchers of medieval art, principally art historians, have in recent years turned their attention to questions concerning the formative presence of materials and concepts of materiality in medieval culture. This has prompted a series of important publications ${ }^{3}$.

Polychrome sculptures dating from the $12^{\text {th }}$ century with remarkably well-preserved original polychromy survive in Norway. Among these are several works that have never been overpainted. The oldest type of extant sculptures is the crucifix, which also survives in the largest numbers, followed by representations of the seated Virgin with Child. There is also a small group of representations of saints ${ }^{4}$. No independent freestanding panel paintings survive from the $12^{\text {th }}$ century, although there are examples of sculpture with two-dimensional paintings on the cross. The resurrection scene of Adam on the lower member of the cross of the crucifix from Horg I (c. 1175-1200 ${ }^{5}$, fig. $1,2)$ and the painted cross of unknown provenance (c. 1150-1200) ${ }^{6}$ are two such examples ${ }^{7}$. Thought early examples of two-dimensional paintings are few in the period before c. 1250. Valuable knowledge has been drawn from investigations in Norwegian group of frontals ${ }^{8}$. Therefore, a clear distinction between painting and sculpture is not stressed here.

\footnotetext{
${ }^{2}$ ELKINS, James - "On Some Limits of Materiality in Art History". in NEUNER, Stefan; GELSHORN, Julia (ed.) - Taktilität: Sinneserfahrung als Grenzerfahrung: Das Magazin des Instituts für Theorie 12, 2008, pp. 25-30.

${ }^{3}$ BYNUM, Caroline Walker - Christian Materiality: An Essay on Religion in Late Medieval Europe. New York: Zone Books, 2011; KUMLER, Aden; LAKEY, Christopher R. - "Res Et Significatio: The Material Sense of Things in the Middle Ages". Gesta 51, 2012; WILLIAMSON, Beth - "Material Culture and Medieval Christianity". in ARNOLD, John H. (ed.) - The Oxford Handbook of Medieval Christianity. Oxford, 2014; PENTCHEVA, Bissera V. - The Sensual Icon: Space, Ritual, and the Sences in Byzantium. Pennsylvania: The Pennsylvania State University Press, 2010.

${ }^{4}$ Such as the head from Urnes (Inv. no. MA 77) and a seated full figure sculpture from Urnes (Inv. no. MA 316), whose identity is uncertain. St Olav has been suggested. Both are in the University Museum of Bergen.

${ }^{5}$ BLINDHEIM, Martin - Painted Wooden Sculpture in Norway c. 1100-1250, Medieval Art in Norway. Oslo: Scandinavian University Press, 1998, cat. no. 12.

${ }^{6}$ Inv. no. C 33267, MCH. BLINDHEIM, Martin - Painted Wooden Sculpture..., cat. no. 23.

7 PLAHTER, Unn - "Noen observasjoner i 1100-tallets bemaling sett i relasjon til antemensalemaleriet". Paper presented at the Nordisk konservatorforbund's 9. Kongress. Oslo, 1981, pp. 71-78; PLAHTER, Unn - "Norwegian Art Technology in the Twelfth and Thirteenth Centuries: Materials and Techniques in a European Context”. Zeitschrift für Kunsttechnologie und Konservierung 28/1, 2014, pp. 306-307.

${ }^{8}$ PLAHTER, Unn - Painted Altar Frontals of Norway 1250-1350, vol. 2: Materials and Technique. London: Archetype Publications Ltd., 2004.
} 


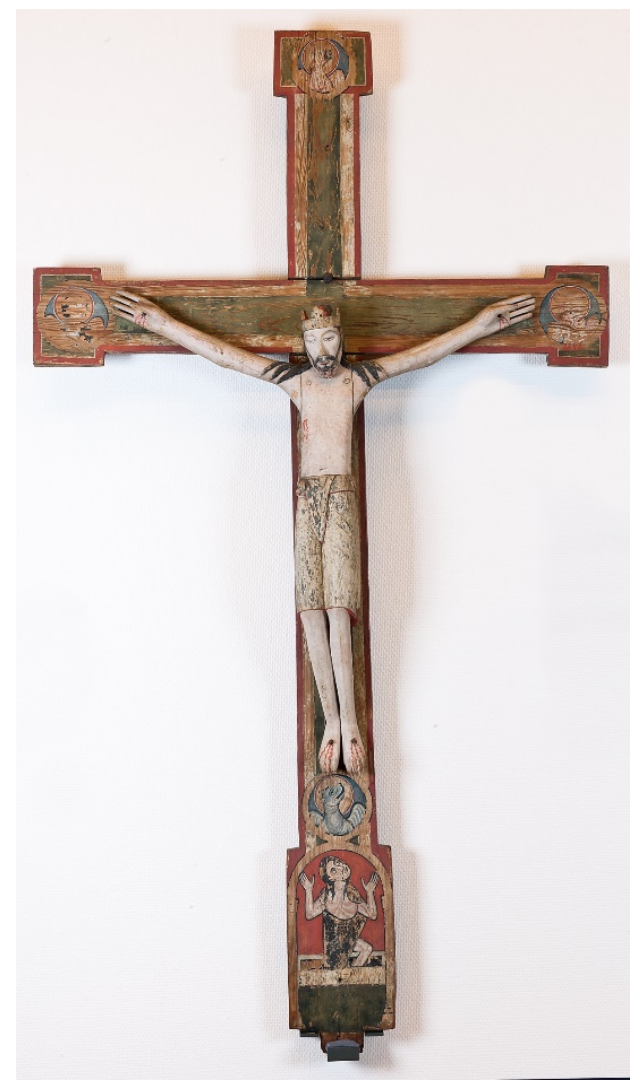

Fig. 1 - Crucifix from Horg I, c. 1175-1200. Cross: 158 x 98 x $\sim 2 \mathrm{~cm}$. Figure: 74 x 67.5 x $9 \mathrm{~cm}$. Inv. no. T 4646. (Photo $@$ C University Museum, Trondheim (NTNU))

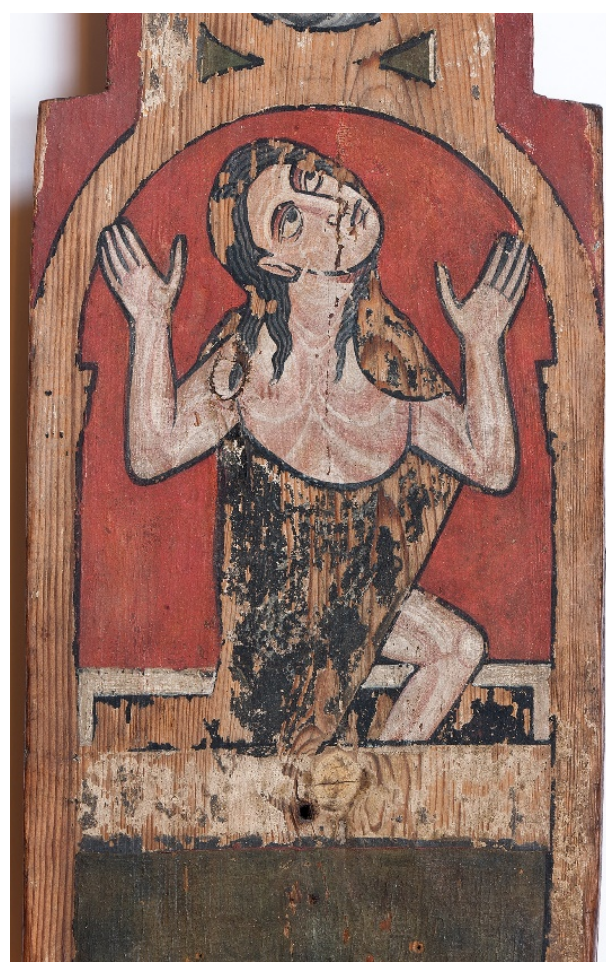

Fig. 2 - Detail of the resurrection scene of Adam on the lower end of the cross stem. (Photo $\mathbb{C}$ University Museum, Trondheim (NTNU)) 


\section{Objects investigated}

A catalogue on the majority of the sculpture from this period is written by Blindheim ${ }^{9}$. A statistical overview of the preserved sculpture dated to before 1350 has been presented by Kaja Kollandsrud ${ }^{10}$, and includes objects from former Norwegian territory that are now present-day Sweden (Härjedalen, Bohuslän). An overview of painting materials and their application identified in $12^{\text {th }}$ and $13^{\text {th }}$-century painting and sculptures has been published by Unn Plahter and revealed some clear trends in the painting techniques and appearances ${ }^{11}$.

The sculptures that have survived from before the mid- $13^{\text {th }}$ century are fewer in number and show less cohesion in the choice of materials than the more consistently produced group of objects that follows. The largest and most technically and stylistically cohesive group of medieval sculptures is dated to the second half of the $13^{\text {th }}$ century. There are also 31 panel paintings, the frontals produced in Norway, which are dated between 1250 and $1350^{12}$. These represent the largest coherent group of panel paintings in northern Europe.

Two sculpted frontals, with three-dimensional micro architecture framing scenes containing relief sculpture, are also preserved $^{13}$. Since the painting and gilding techniques identified in the frontals and sculpture from the period are basically the same, the analyses of the two-dimensional panels represent an important reference for the three-dimensional sculpture and vice-versa. The same painters seem to have worked

\footnotetext{
${ }^{9}$ BLINDHEIM, Martin - Painted Wooden Sculpture in Norway c. 1100-1250. Medieval Art in Norway. Oslo: Scandinavian University Press, 1998. The catalogue includes three works of metal and one of morse ivory. See also BLINDHEIM, Martin - Gothic Painted Wooden Sculpture in Norway 1220-1350. Oslo: Messel forlag, 2004.

${ }^{10}$ KOLLANDSRUD, Kaja - "Technological Mapping of Norwegian Polychrome Wooden Sculpture, 1100-1350: a Preliminary Overview". in HOFSETH, Ellen H. (ed.) UKM skrifter 1. Oslo: Universitetets kulturhistoriske museer, 2002, pp. 125-141.

${ }^{11}$ PLAHTER, Unn - "Norwegian Art Technology...".

${ }^{12}$ MORGAN, Nigel J. - "4 Dating, Styles and Groupings". in HOHLER, Erla B.; MORGAN, Nigel J.; WICHSTRØM, Anne - Painted Altar Frontals of Norway 1250-1350, vol. 1: Artists, Styles and Iconography. London: Archetype Publications Ltd., 2004, pp. 20-38.

${ }^{13}$ KOLLANDSRUD, Kaja; HUTH, Nadine - "Beyond the Precious with Painterly Effects: The Thirteenth Century Sculpted Frontal from Komnes, Buskerud in Norway”. in GRINDER-HANSEN, Poul (ed.) - Image and Altar 800-1300. Papers from an International Conference in Copenhagen 24-27 October. Copenhagen: PNM Publications from the National Museum Studies in Archaeology \& History, 2014, pp. 229-246.
} 
on panels and sculpture. The similar materials and painting techniques registered on sculpture and painting in a tabernacle supports this view ${ }^{14}$. There is no strong evidence for a distinct specialist craft of polychrome painters until the late $15^{\text {th }}$ century ${ }^{15}$. In addition to published case studies, unpublished reports on individual sculptures are available in the museum archives, while other objects remain to be investigated.

Old Norse text are observed on strips of parchment across the joins in the wooden support of the frontals from Årdal II and Tresfjord, and are painted on the frontal from Nedstryn ${ }^{16}$. Runic inscriptions, cut with a knife into the wood surface, are found on his right arm, loincloth and leg of the crucifix from Lunder (c. 1250) ${ }^{17}$. These findings of Old Norse text and runes strongly indicate Norwegian origin.

According to Nigel Morgan, "there seems no reason to think that the art of Western Norway in this period was far behind developments in England and France, in view of the international economic, cultural and dynastic contacts of the Norwegian royal family resident in Bergen" 18 .

\section{Norway's relations}

Scandinavia's peripheral position in the north seems to be a minor obstacle for its cultural relations with Western Europe ${ }^{19}$. It is clear from the evidence examined that both the making and the perception of Catholic church art in medieval Norway was firmly rooted in the tradition of the old church fathers, fully in line with Christian

\footnotetext{
${ }^{14}$ PLAHTER, Unn - Painted Altar Frontals..., pp. 195-199.

15 NADOLNY, Jilleen - "One Craft, many Names: Gilders, Preparers, and Polychrome Painters in the $15^{\text {th }}$ and $16^{\text {th }}$ Centuries". in Art technical source research. ICOM-CC, 2008, pp. 10-17.

${ }^{16}$ PLAHTER, Unn - Painted Altar Frontals..., pp. 17-18, 187-188.

17 Inv. no. C 11703, MCH. BLINDHEIM, Martin - Painted Wooden Sculpture..., cat. no. 62. KOLLANDSRUD, Kaja - "340 Kruzifix aus Lunder". in KROKER, Martin (ed.) - Credo. Christianisierung Europas im Mittelalter. Katalog Band II, VI Sterbende Götter: Christianisierung Skandinaviens. Petersberg: Michael Imhof Verlag, 2013, pp. 340-341.

${ }^{18}$ MORGAN, Nigel J. - "4 Dating, Styles and Groupings"..., p. 23.

19 BLINDHEIM, Martin - "Scandinavian Art and Its Relations to European Art around 1200". in The Year 1200: A Symposium. New York: The Metropolitan Museum of Art, 1975, p. 429.
} 
paradigms found in the rest of Europe $\mathrm{e}^{20}$. The Church and the religious orders functioned across national borders. Political and commercial alliances naturally led to the exchange of works of art and craftsmen, and with them moved stylistic impulses, materials and personal skills. A substantial number of artefacts bear evidence of continuous cultural exchange established through the movement of people, knowledge and cultural influences in the well-connected networks and organized wide-ranging trade. This cultural exchange had important consequences for the range of raw materials available to the artisan, and the interpretation of polychromy in a theological-philosophical perspective. As a seafaring nation facing the North Sea, Norway maintained a special relationship with Britain from an early date ${ }^{21}$. According to Øystein Ekroll, this relation was well-established in the period discussed here, while the Swedes, Danes and the Baltic seem to have had greater association with Lower Saxony and the Rhineland. Ildar Garipzanov points out how earlier historical research has tended to be anglophile in nature, and posits one of the reasons for this focus as a lack of knowledge among the researchers of the Eastern Church $^{22}$.

Cultural exchange flourished within the eastern and southern regions of Europe and it is clearly demonstrated in the materiality of the diverse types of objects discussed here ${ }^{23}$. Norway and Western Europe had their closest contact with the art of Byzantium throughout the period between 1100 and $1250^{24}$. Several examples of the mutual interchange of objects and ideas are discussed by Bosselmann-Ruickbie ${ }^{25}$. David Talbot Rice concludes that relations between Britain and the East Mediterranean World can be

\footnotetext{
${ }^{20}$ KOLLANDSRUD, Kaja - Evoking the Divine: The Visual Vocabulary of Sacred Polychrome Wooden Sculpture in Norway between 1100 and 1350. Oslo: University of Oslo, 2018. PhD thesis.

${ }^{21}$ EKROLL, Øystein - "Erkebiskop Eystein, Oktogonen i Kristkyrkja og Kristi Gravkyrkja i Jerusalem". in BJØRLYKKE, Kristin et alii (ed.) - Eystein Erlendsson - Erkebiskop, politiker og kirkebygger. Trondheim: Nidaros domkirkes restaureringsarbeiders forlag, 2012.

${ }^{22}$ GARIPZANOV, Ildar - "Wandering Clerics and Mixed Rituals in the Early Christian North, c. 10001150”. The Journal of Ecclesiastical History 63/1, 2012, pp. 1-17.

${ }^{23}$ BOSSELMANN-RUICKBIE, Antje - "Contact between Byzantium and the West from the $9^{\text {th }}$ to the $15^{\text {th }}$ Century: Reflections in Goldsmiths' Works and Enamels". in DAIM, Falko; HEHER, Dominik; RAPP, Claudia (ed.) - Menschen, Bilder, Sprache, Dinge Wege der Kommunikation zwischen Byzanz und dem Westen 1: Bilder und Dinge. Studien zur Ausstellung 'Byzanz \& der Westen. 1000 vergessene Jahre'. Mainz: Verlag des Römisch-Germanischen Zentralmuseums, 2018, pp. 73-104.

${ }^{24}$ KITZINGER, Ernst - "The Byzantine Contribution to Western Art of the Twelfth and Thirteenth Centuries". Dumbarton Oaks Papers 20, 1966, p. 27.

${ }^{25}$ BOSSELMANN-RUICKBIE, Antje - "Contact between Byzantium and the West...".
} 
better understood when he interprets Byzantine in a wider sense ${ }^{26}$. Links between the origins of the painterly techniques in the northern arts and Byzantine tradition are numerous in the period discussed here, for example the use of a dark underpaint, as well as the use of lapis lazuli in the blue ${ }^{27}$. Winfield finds that Romanesque painting methods can, at least technically, be regarded as a simplified and adapted version of the Byzantine painting ${ }^{28}$. These views accord with $12^{\text {th }}$-century art in Norway, as the application of paint and design, made with contrasting colours, follow a similar system of layers as the Byzantine tradition.

Although this acknowledges the strength of stylistic influence, Ernst Kitzinger warned of not going as far in assuming direct communication, stating that "Byzantium is not a universal key" 29 . He stresses that this may have been a factor of some importance "as early as the year one thousand when the Ottonian style was reaching maturity in the West, and Constantinople was distilling the classical revivals of the 'Macedonian renaissance' a mature mediaeval style on its own." Furthermore, he points to the phenomena of parallelism between the East and the West in this period, as currents of practice could branch off the mainstream and enter Western art, as distinct from and in addition to direct influences. Consistent parallel trends in the painterly techniques have been identified as characteristic for the group of $12^{\text {th }}$-century polychrome sculptures ${ }^{30}$. In Sweden, Peter Tångeberg has posited that the scarcity of the preserved material in Europe at this time makes it difficult to draw general conclusions. In his major publication on wooden sculpture and altar decorations in Sweden, first published in 1986, he does however, present trends in the Swedish material that are similar to those found in Norway ${ }^{31}$.

${ }^{26}$ RICE, David Talbot - "The Britain and the Byzantine World in the Middle Ages". in VOLBACH, Wolfgang Fritz (ed.) - Byzantine Art - A European Art. Lectures. Athen: Department of Antiquities and Archaeological Restoration, 1966, p. 23.

${ }^{27}$ David Winfield was early to point this out: WINFIELD, David C. - "Middle and later Byzantine Wall Painting Methods. A Comparative Study". Dumbarton oaks Papers. Washington: Dumbarton Oaks Centre for Byzantine Studies, Trustees for Harvard University, 1968, p. 100; PLAHTER, Unn - Painted Altar frontals..., p. 191; PLAHTER, Unn - "Norwegian Art Technology...", pp. 311-314; PLAHTER, Unn - "Noen observasjoner i 1100-tallets...", p. 77.

${ }^{28}$ WINFIELD, David C. - "Middle and later Byzantine Wall Painting...", p. 129.

${ }^{29}$ KITZINGER, Ernst - "The Byzantine Contribution...", pp. 39-40.

${ }^{30}$ PLAHTER, Unn - "Norwegian Art Technology...". pp. 307-310.

${ }^{31}$ TÅNGEBERG, Peter - Holzskulptur und Altarschrein... 


\section{Art technological characteristics}

The following is not an overview, rather a presentation of some characteristics of the painter's technology of the $12^{\text {th }}$ and early $13^{\text {th }}$ century. Furthermore, it proposes some possible paths that research might take to improve our understanding of them. This is seen in the perspective of the material preserved in the north. The aim is to illustrate the potential in shared contributions that can deepen our collective knowledge.

\section{The wooden core}

The identification of the type of wood used in the various parts that make up an object, and their individual function, has made it possible to better understand how artisans made use of the different kinds of wood. An overview of the wood species identified in the material preserved in Norway, their size, availability, trade and workability, was given by Plahter ${ }^{32}$. Botanical analyses were initiated by Martin Blindheim in the 1960's and comprised 120 polychrome wooden sculptures and 32 boards used in crosses and tabernacle constructions ${ }^{33}$.

These botanical analyses reveal that medieval sculptures assigned to the various regions of Norway were carved in wood from the following tree genera: Alnus sp., Betula sp., Fraxinus sp., Populus sp., Quercus sp., Salix sp., Sorbus sp., Tilia cordata and Pinus silvestris. On these grounds, the following types of wood were recognised: alder, birch, ash, aspen, oak, great sallow, rowan, lime and pine. This use of a rather wide range of different types of wood has been found to be a characteristic feature for sculptures dated to the period before c. 1225 and agrees with Tångeberg’s findings in the Swedish material $^{34}$.

\footnotetext{
${ }^{32}$ PLAHTER, Unn - "Norwegian Art Technology...”, pp. 299-301, and appendix I, table 2, pp. 320-324.

${ }^{33}$ The botanical analyses were performed by professor Elias Mork, Norges Landbrukshøyskole, professor Trygve Braarud and Dr. Kari Henningsmoen, University of Oslo. Results were published by BLINDHEIM, Martin - Painted Wooden Sculpture... and BLINDHEIM, Martin - Gothic Painted Wooden Sculpture...

${ }^{34}$ TÅNGEBERG, Peter - Holzskulptur und Altarschrein...
} 
Interestingly, various types of wood were used for both large (more than $1 \mathrm{~m}$ tall) and small objects. No clear preference for oak can be found, and a preference for soft wood instead of dense wood was not identified. Hence, the handling properties of the wood may seem to have been of less concern to the carver, who would have had to rely on the sharpness of the tools. A smooth finish and narrow cuts indicate fold lines, and a thin ground for whitening seems to have been sufficient. These are features Klaus Endemann classified as the pre-Gothic carpentry technique and are recognised in Norwegian sculpture ${ }^{35}$.

Notably, the $90 \mathrm{~cm}$ tall seated Virgin from Dyste (c. $1225^{36}$, fig. 3) provides an example of an object where several different types of wood were chosen for its construction in accordance with their properties and function ${ }^{37}$. The finely detailed main core is worked in lime (Tilia cordata); a soft and easily carved timber with little grain, that makes it easy to cut across the fibre. The chair's posts are turned in beech (Fagus, sp.), as its fine tight grain makes it particularly suitable for turnery. Beech, on the other hand, has not been used for the main core of sculptures in this period. As beech reduces seriously in volume upon seasoning, this may seem reasonable ${ }^{38}$. The pegs that secure the turned beech posts to the main lime block on Dyste are made in oak (Quercus sp.), as its dense hard quality renders it ideal for this purpose.

\footnotetext{
${ }^{35}$ ENDEMANN, Klaus - "Zur Holzskulptur des Frühen Mittelalters. Voraussetzungen und Funktion Schnitztechnik und Fassung”. Zeitschrift für Kunsttechnologie und Konservierung 26/2, 2012, pp. 400434.

${ }^{36}$ BLINDHEIM, Martin - Painted Wooden Sculpture..., cat. no. 37.

37 SELSJORD, Marianne - "The 'Golden Madonna' from Dyste Church". in Yearbook of the Historical Archives of Historical Art Technology. Technologia Artis. Prague: The Union of Czech Artists in collaboration with the Institute for Art history ${ }^{\wedge} \mathrm{CSAV}$ and the Academy of Fine Arts in Prague, 1993, pp. 113-116.

${ }^{38}$ PLAHTER, Unn - "Norwegian Art Technology...”, p. 300.
} 


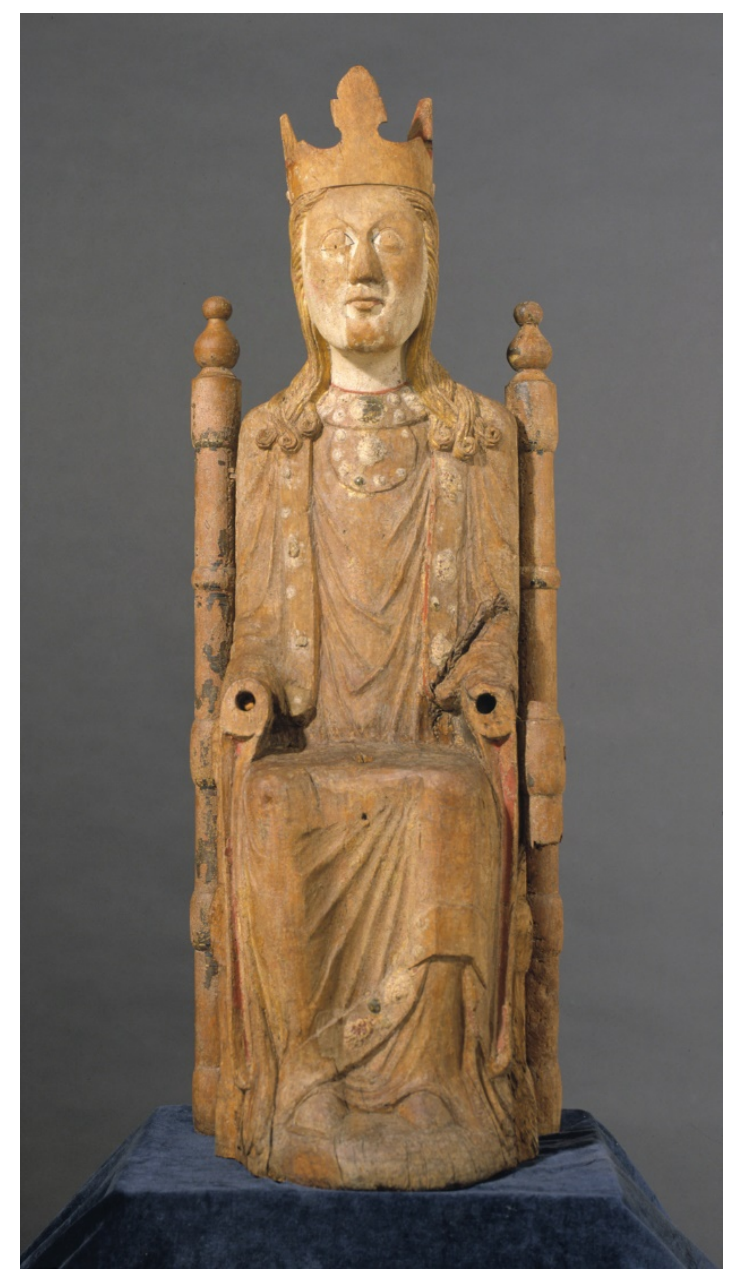

Fig. 3 - Virgin from Dyste, c. 1225, 90 x 31.5 x 24 cm. Inv. no. C 1525, MCH.

(Photo: Marianne Selsjord (C) MCH, UiO)

After 1200 an increasing use of oak is recorded and its availability seems to have met the growing demands for larger components. One may speculate whether a shift in forest conditions during The Medieval Climatic optimum (900-1300 AD) gave rise to increased growth of oak, facilitating the demands. Unlike the thin preparation layers normally found in the period that follows, the ground now served additional purposes such as levelling tool marks, adjusting volumes and obtaining relief. Thus, the ground layers are most often applied rather thickly. Boards are most commonly made out of pine and oak. Oak is split radially into boards, while pine is split in two halves and one tangential board is hewn from each half. Sawn boards were introduced after the watersaw came into common use in Norway during the $16^{\text {th }}$ century ${ }^{39}$.

\footnotetext{
${ }^{39}$ PLAHTER, Unn - Painted Altar Frontals..., vol. 2, pp. 4-5.
} 
It is important that further mapping of the use of various types of wood, their function and the following surface finishing can provide valuable information on regional differences, provenance and contribute to the dating of sculpture.

\section{The ground}

The use of grounds of chalk bound with aqueous media, and the parallel instances of oil grounds, or the use of both when targeted for specific areas in the painting, is a feature in the early objects before chalk ground becomes the dominant choice in the north. Chalk is a white marine sediment, mainly composed of coccoliths that cover the minute marine algae. Coccolith assemblages are important in dating of marine sediments. Thus, geological age and the possible location of chalk deposits can be suggested. As chalk deposits do not occur in Norway, this material had to be imported. Hence the provenance of chalk in art bears an important marker for cultural exchange.

So far, analyses of chalk sampled from art in Norway indicate that they were sourced from two main regions with chalk, referred to as Continental and Channel Region Chalk further to the west ${ }^{40}$. Interestingly, a shift from a dominant use of Continental to a preference for Channel Region Chalk took place in the mid- $13^{\text {th }}$ century. It has been argued that this shift did not follow the change in trade routes but rather coincided with an increasing stylistic influence from the West, accompanied by technological preferences, linked to workshop traditions.

During the last decades, improved characterisation of chalk deposits in Northern Europe may give rise to narrower distinguishable provenances. Thus, a re-investigation of chalk sampled from art, combined with improved knowledge on chalk deposits, may provide more precise chalk provenance. In consequence, a better picture of trade routes may emerge.

\footnotetext{
${ }^{40}$ PERCH-NIELSEN, Katharina von Salis; PLAHTER, Unn - "Analyses of Fossil Coccoliths in Chalk Grounds of Medieval Art in Norway". in MALMANGER, Magne; BERCELLY, Lazlo; FUGLESANG, Signe (ed.) - Norwegian Medieval Frontals. Acta ad archaeologiam et artivm historiam pertinentia XI. Papers from the Conference in Oslo December 1989. Roma: Giorgia Bretschneider, 1995, pp. 145-156.
} 
While gypsum is commonly associated with the art of Italy, the use of gypsum, or combinations of gypsum and chalk, has also been identified in specific instances elsewhere in Europe ${ }^{41}$. Anette Scholtka argues that such occurrences in the north seem most common in objects that predate the $13^{\text {th }}$ century. A Norwegian example is found in the Virgin from Urnes (c. 1175, fig. 4) where a rich layer of gypsum was applied over an underlayer of chalk ${ }^{42}$. This layer of gypsum was present both in the painted areas, and in those receiving tin gilding (see below), but was absent in a cross-section sampled from the flesh ${ }^{43}$. The even interface between the chalk and gypsum layers observed in the cross-sections indicates that the former was levelled and smoothed before the gypsum was applied (fig. 5).

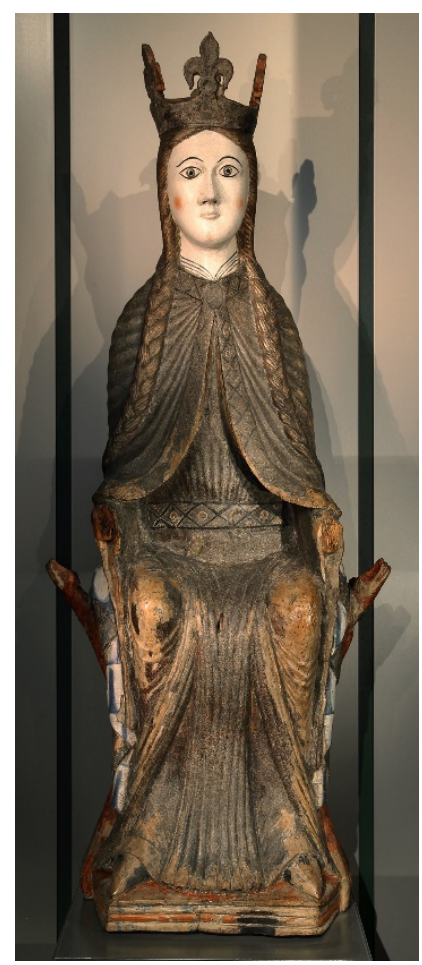

Fig. 4 - Virgin from Urnes, c. 1175.120 x 60.5 x 22.5-24.5 cm. Inv. no. MA 46,

University museum of Bergen. (Photo (C) Stephan Kuhn)

\footnotetext{
${ }^{41}$ See table of gypsum identified in grounds in SCHOLTKA, Annette - "Theophilus Presbyter - Die maltechnischen Anweisungen und Ihre Gegenüberstellung mit naturwissenschaftlichen Untersuchungsbefunden". Zeitschrift für Kunsttechnologie und Konservierung 6/1, 1992, pp. 44-45.

${ }^{42}$ SEM-EDX analysis performed by Kollandsrud in 2002 on a SEM Jeol 840 in combination with energy dispersive X-ray analyser (EDX Link AN10000). The straight border between the layers are clear in the colour mapped cameo image from the cross-section sampled from the outside of the mantle.

${ }^{43}$ It is not certain whether this was intended or if the gypsum top layer was simply removed during the careful smoothing of the ground. Though the gypsum layer is rather thick in the other samples. This was a re-examination of existing samples collected by conservator Bjørn Kaland, University of Bergen, 1959. New analysis might solve this issue.
} 


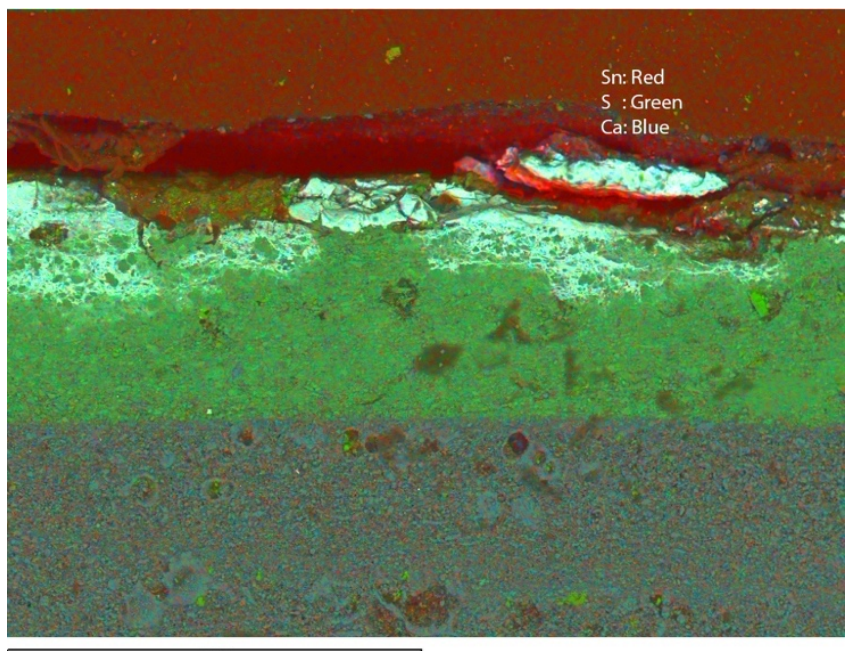

Fig. 5 - Cameo photo based on back scatter SEM-EDX image of a cross-section from the imitation gold based on tin on a chalk ground coated with gypsum from the outside of the Virgin's mantle. The straight surface of the chalk ground indicates that it was smoothed before the application of the gypsum. Sn: White, S: Blue, Ca: Blue.

(Photo: Kaja Kollandsrud (C) MCH, UiO)

The crucifix from Hemse (c. 1170), Gotland, Sweden, is an example where the wood was partially covered by a thin pinkish oil-bound preparation layer that forms a substratum for the white oil ground. However, the imitation of raised precious stones are not carved in wood, but formed in glue-bound chalk applied directly to the wood surface $^{44}$. A similar strategy was applied to the crucifix from Alskog, Väte and Endre, in Gotland, Sweden ${ }^{45}$. In these cases, all gilded areas were carried out on chalk ground while the remaining areas in oil paint were applied to an oil bound ground. Interestingly, recent publication of the Hoven Madonna, a Cologne work, dated to c. 1170 , also reveals that the lead white ground and paint layers are exclusively bound in oil $^{46}$.

Obviously more evidence of the use of the diverse materials identified in the grounds will be collected gradually, and enable researchers to better understand the diverse craft

${ }^{44}$ PLAHTER, Unn - "The Crucifix from Hemse: Analyses of the Painting Technique". in NADOLNY, Jilleen (ed.) - Medieval Painting in Northern Europe. Techniques, Analysis, Art History. London: Archetype, 2006 (First printed 1984), pp. 11-20; pp. 11-12.

${ }^{45}$ TÅNGEBERG, Peter - Holzskulptur und Altarschrein..., pp. 62-65; PLAHTER, Unn - "Norwegian Art Technology...”, pp. 301-303.

${ }^{46}$ URBANEK, Regina - "Die Hovener Madonna - Bestand und Bewertung". Zeitschrift für Kunsttechnologie und Konservierung 30/2, 2016, pp. 261-280. 
traditions. Furthermore, this will contribute information that better identifies the provenance of sculpture, and broadens knowledge of the craftsmen involved in the cultural exchanges that produced them.

\section{Colouring material}

Colouring materials, identified on art from the period discussed, are predominantly lapis lazuli/ultramarine for the blue, copper green, green earth or orpiment mixed with carbon black for the green, orpiment for the yellow, red lead or/and vermilion for the red and finally lead white and charcoal black for white and black. A golden effect was largely made with tin covered with a yellow resinous glaze or with gold leaf. In the $13^{\text {th }}$ century, azurite gradually replaced lapis lazuli and silver leaf replaced tin foil. As drying oil medium was increasingly used, red glazes and glazes with copper green as well as yellow glaze with a sienna resembling ochre were favoured in painted areas.

\section{The binding media}

Instrumental analyses have not been used for the identification of media on the Norwegian $12^{\text {th }}$ - and early $13^{\text {th }}$-century painting, but solubility tests, appearances and the presence of grey underpaints for blue and green (veneda) all suggest that water miscible media dominate. A gradual move from water miscible media in the $12^{\text {th }}$ century to the full exploitation of the properties of oil as a binder in the $13^{\text {th }}$ century appears to have taken place. Contrasting pure, saturated opaque colours govern a "lively painted style" while gilding and gemstones, both imitated and real, are characteristic of the "golden style". These styles that dominate this early period, have been the centre of attention for researchers in this field across Europe, over the last 50 years ${ }^{47}$.

\footnotetext{
${ }^{47}$ BRACHERT, Thomas - "Fassung von Bildwerken: Geschichte". in Reallexicon zur deutschen Kunstgeschichte, vol. 7. München: Beck, 1981, pp. 793-798; KARGÈRE, Lucretia; RIZZO, Adriana "Twelfth-Century French Polychrome Sculpture in The Metropolitan Museum of art: Materials and Techniques", Metropolitan Museum Studies in Art, Science, and Technology 1, 2010, pp. 39-72; MERCIER, Emmanuelle; SANYOVA, Jana - "Art et techniques de la polychromie romane sur bois dans dans l'Europe du Nord". Les Cahiers de Saint-Michel de Cuxa, XLIII, 2012, pp. 125-135; JÄGER, Elisabeth - "Zur Polychromie der Kölner Skulptur vom 12.- Bis zum Ende des 14. Jahrhunderts". in BERGMANN, U. (ed.) - Schnütgen-Museum: Holzskulpturen des Mittelalters (1000-1400). Köln: Schnütgenmuseum, 1989, pp. 99-104; SERCK-DEWAIDE, Myriam - "The History and conservation of the surface coating on European gilded-wood Objects". in BIGELOW, D.; CORNU, E.; LANDREY, G.
} 
Drying oil was increasingly used in the $13^{\text {th }}$ century, and apparently in an orderly manner. Hence, unmodified linseed oil was favoured for opaque oil-based paints and wet-in-wet modelling, while the heat-bodied oil with some resin was preferred for the glazes and layered structures. As the use of heat-bodied oil lessens changes in volume during drying, the risk of paint deformation is reduced. Thus, heat-bodied oil made it possible to work with thick glazes. A content of resin in the heat-bodied oil has normally been considered to improve transparency. Plahter, however, has suggested that resin may remain from a balsam used as solvent in order to improve flow ${ }^{48}$.

\section{The binding media}

The grey layer described by Theophilus as veneda, was recommended as underpaint for blue and green layers and has been found for glue-bound blue and green paints ${ }^{49}$. Scholtka claims that Theophilus only found it necessary to use veneda under green and blue in wall paintings ${ }^{50}$. The veneda will improve the appearance of these structures only if water-miscible opaque paint is used. The grey underpaint will, in addition to supplying a bluish tinge, absorb light and serve to lessen scattering. Thus, colour intensity is retained in the glue-bound paint, were voids in the surface due to loss of water also causes light scattering ${ }^{51}$.

In the crucifix from Horg I (c. 1175-1200, fig. 1), a grey veneda layer, is observed under the copper green and blue lapis lazuli ${ }^{52}$. A similar veneda, made from lead white mixed with charcoal black, was identified under the blue garments in the sculptures of St John and Mary that accompany the crucifix in the Calvary group from Urnes (c. 1150, fig. 6, $7)^{53}$. No examples of veneda in $13^{\text {th }}$-century sculpture in Norway have been identified to

J.; VAN HORNE, C. (ed.) - Gilded Wood, Conservation and History. Sound View Press, Madison (CT), 1991, pp. 65-73; TÅNGEBERG - Holzskulptur und Altarschrein...

48 PLAHTER, Unn - Painted Altar Frontals..., vol. 2, p. 200; PLAHTER, Unn - "Norwegian art technology...", p. 315.

${ }^{49}$ PLAHTER, Unn - Painted Altar Frontals..., vol. 2, p. 191; PLAHTER, Unn - "Norwegian Art Technology...", p. 314, n. 124; KLOCKE, Jens; LEHMANN, Jirina - "Technik des Unterlegens von grobkörnigen Pigmenten: die Veneda des Theophilus". Restauro 107/5, 2001, pp. 373-375.

${ }_{50}$ SCHOLTKA, Anette - "Theophilus Presbyter- Die maltechnischen Anweisungen..., pp. 32, 34.

${ }^{51}$ PLAHTER, Unn - Painted Altar Frontals..., vol. 2, p. 191; PLAHTER, Unn - "Norwegian Art Technology...", p. 314.

52 PLAHTER, Unn - Painted Altar Frontals..., vol. 2, pp. 190-191.

${ }^{53}$ FRØYSAKER, Tine; KOLLANDSRUD, Kaja - "The Calvary Group in Urnes Stave Church, Norway: A Technological Examination". in NADOLNY, Jilleen (ed.) - Medieval Painting in Northern Europe: Techniques, Analysis, Art History. London: Archetype, 2006, pp. 51-52. 
date, but it is found under a layer of azurite in a chalk painting at Tanum church, dating close to $1300^{54}$.

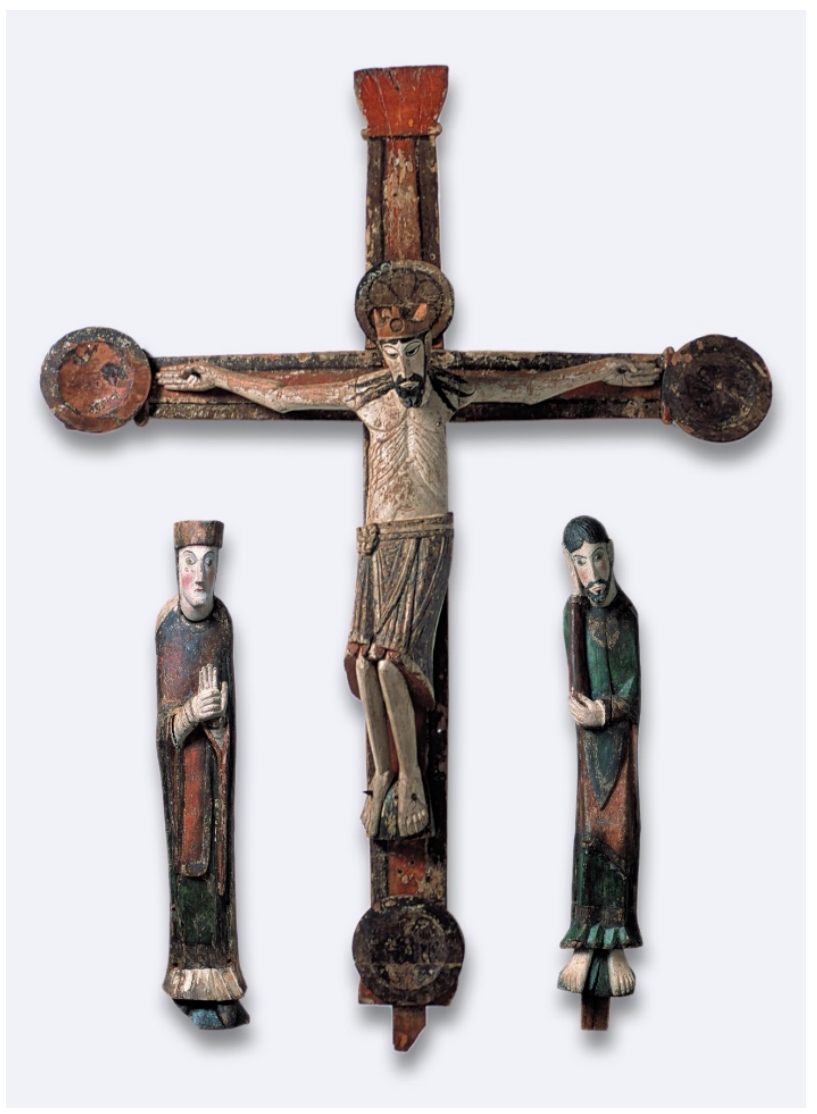

Fig. 6 - Calvary group from Urnes, c. 1150. After restoration in 2003 by Tine Frøysaker. The circular disks on the cross ends and the present polychrome on Mary and St John is believed to date to the thirteenth century. Cross 224 x $156 \mathrm{~cm}$. Now in situ Urnes stave church.

(Photo: Birger R. Lindstad (C) NIKU)

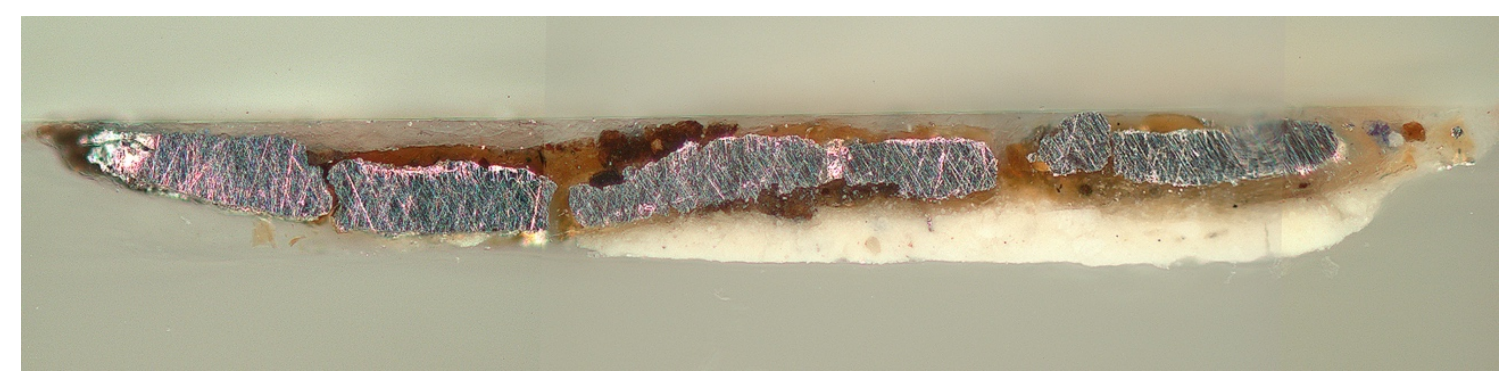

Fig. 7 - Cross section of well-preserved yellow glazed tin foil from the border edging of the loincloth of the Urnes Christ figure. 100x. (Photo: Kaja Kollandsrud ( $\mathrm{MCH}, \mathrm{UiO}$ )

54 PLAHTER, Unn - unpublished report 1976, MCH. LAMARK, Wenche G. H. - Tanum Kirkes Kalkmalerier. University of Oslo, Department of art history, 2009. Master thesis. 
Light underpaints for the translucent green and blue oil paints, on the other hand, will increase reflection and intensify the bright luminance of these colours. It is an important observation that the use of lead white underpaint for unrefined lapis lazuli indicates an early understanding of the properties of this pigment in oil. The low refractive indices of the colourless minerals in the stone act as translucent extenders, while the white underpaint serves to increase the reflection and thereby intensifies the brightness of translucent oil-based colours ${ }^{55}$. The parallel use of dark underpaints for specific colours such as blue and green in the Byzantine world and the white underpainting, which developed in the West, was probably related to differences in translucency created by the media.

\section{The making of green and blue structures}

The many different ways of making green tones in aqueous-based paint is a characteristic for the $12^{\text {th }}$ century. The less vivid water-miscible green paints were prepared in various ways: copper green on grey underpaint (veneda), mixtures of yellow and blue or yellow and black pigments as well as green earth. These varieties became redundant when copper green bound in oil, that produces a vivid saturated and transparent green, came into used towards the second quarter of the $13^{\text {th }}$ century, seemingly throughout Europe ${ }^{56}$.

Twelfth century blue paints are normally made with lapis lazuli, while in the $13^{\text {th }}$ century it was gradually replaced by azurite in most regions of Europe ${ }^{57}$. Both blue pigments are found in water-miscible as well as oil media. A great potential can be found in new opportunities brought about by modern media analyses. A more detailed understanding of the layer structure and binding mediums used for blue and green may shed further light on the development and use of aqueous-based paint systems and the early use of oil.

\footnotetext{
${ }^{55}$ Early examples are the loincloths of the crucifix in the Calvary group from Urnes (c. 1150) and the crucifix from Hemse, Gotland in Sweden, (c. 1175). FRØYSAKER, Tine; KOLLANDSRUD, Kaja "The Calvary Group in Urnes..., p. 50; PLAHTER, Unn - "The Crucifix from Hemse...", pp. 14-15.

${ }^{56}$ PLAHTER, Unn - "Norwegian Art Technology....", p. 308, 314; PLAHTER, Unn - Painted Altar Frontals..., vol. 2, p. 192.

${ }^{57}$ PLAHTER, Unn - "Norwegian Art Technology....", pp. 317-318.
} 


\section{Gold and golden appearances}

Gilding, executed in a range of metals and coatings, makes up an important part of the visual aesthetic of the entire medieval period. The various metal gildings are a main motif in "the golden" and "the transparent style", and seen in trimmings and select ornaments in "the lively painted style". The repertoire of metals used in medieval gildings, their application, coatings and visual effect is further discussed by Kollandsrud $^{58}$.

\section{Matt and glossy: Oil and water gilding}

There are two main methods of attaching metal leaf: "Water gilding" that can be burnished to a high gloss, and "mordant gilding" that produces a matt result, as it cannot be burnished when the mordant base is bound in oil ${ }^{59}$.

Before the introduction of poliments, such as bole, after c. 1350 in Norway (1250 in Italy) ${ }^{60}$, burnished gilding was produced by the process of "ground gilding", where the metal leaf is applied directly to "a meticulously smoothed layer of (chalk or gypsum) ground that has been moistened with a coating of aqueous adhesive, most probably of glair or animal glue" ${ }^{\prime 61}$. Analyses of cross-sections of original gilding show a tendency towards a stronger fluorescence towards the top of the ground. This has been interpreted as resembling glair ${ }^{62}$. Physical reconstruction confirms that the presence of a thin solution of glair, when absorbed into the ground, adds to the flexibility of the ground and contributes positively to achieve a mirror-like surface when polishing the silver. The Icelandic $14^{\text {th }}$ century instruction on how to polychrome a sculpture, Likneskjusmid describes: How the ground is prepared, followed by the silvering that is attached with skrálim (hide glue distemper) directly onto the white ground and the application of

\footnotetext{
${ }^{58}$ KOLLANDSRUD, Kaja - "The Divine Communicated through Embodied Light in Medieval Sculpture in Norway", Selected papers from the conference Science, Imagination, Wonder: Robert Grosseteste and his Legacy. Pembroke College, Oxford University, 3-5 April 2018. Brepols; due 2019.

${ }^{59}$ NADOLNY, Jilleen M. - The Techniques and Use of Gilded Relief Decoration by Northern European Painters, c. 1200-1500. London: University of London, 2001. PhD thesis, p. 121.

${ }^{60}$ NADOLNY, Jilleen M. - "All that's Burnished isn't Bole. Reflections on Medieval Water Gilding: Part 1: Early Medieval to 1300”, in NADOLNY, Jilleen (ed.) - Medieval Painting in Northern Europe..., pp. 148-162.

${ }^{61}$ The term "ground gilding" was first introduced by NADOLNY, Jilleen - The Techniques and Use of Gilded Relief..., vol. I, p. 123.

${ }^{62}$ PLAHTER, Unn - Painted Altar Frontals..., vol. 2, pp. 44-45, sections 2.3 and 2.4.
} 
gullfargi (gold colour) ${ }^{63}$. Likneskjusmið is written as a letter from one craftsman to another. The text is not merely a collection of older recipes but represents contemporary practice in Norway and Iceland. In Ólafur Halldórsson's view (based on linguistic criteria), the original letter was written in the first half of the $14^{\text {th }}$ century ${ }^{64}$.

\section{Gold leaf}

The goldsmith's use of sheet gold attached to the wooden core to gild sculpture prior to the $12^{\text {th }}$ century, has been discussed by Endemann ${ }^{65}$. The painters, however, imitated golden objects by using very thinly beaten gold leaf to gild a wooden support, a far more economical solution. The Virgins from Dyste (c. 1225, fig. 3) and Hove (c. $1230^{66}$, fig. 8) are examples of extensive use of highly polished water gilding with gold leaf on their textiles and the back of the shrine. Real gold is also used in the gildings of loincloths, seen in the crucifix from Ottergy (c. 1225-1250) ${ }^{67}$, and Fjell (c. 1220$1230)^{68}$. The use of gold was often combined with gildings in other metals, discussed below.

${ }^{63}$ MS AM $194.8^{\circ}$ in the Arnamagnæan Institute, University of Copenhagen. PLAHTER, Unn "Líkneskjusmí 0 : $14^{\text {th }}$-Century Instructions for Painting from Iceland". in MALMANGER, Magne; BERCELLY, Laszlo; FUGLESANG, Signe (ed.) - Norwegian Medieval Altar Frontals and Related Material. Roma: Giorgio Bretschneider, 1995, pp. 63, 157. See also WIIK, Svein - "Líkneskjusmíð. Medieval Polychrome Technique in Iceland". Zeitschrift für Kunsttechnologie und Konservierung 9, 1995.

${ }^{64}$ HALLDÓRSSON, Ólafur - “Líkneskjusmið”, Árbók hins islenzka fornleifafélags 1973, 1974. Private communication 1988.

${ }^{65}$ ENDEMANN, Klaus - "Zur Holzskulptur Des Frühen Mittelalters...". This is further discussed in PLAHTER, Unn - "Norwegian Art Technology...", p. 309.

${ }^{66}$ WILLIAMSSON, Paul - Gothic Sculpture 1140-1300. Pelican History of Art, New Haven and London: Yale University Press, 1995, p. 117.

${ }^{67}$ FRØYSAKER, Tine - "Den middelalderske Kristusfiguren fra Otterøy kirke, Namsos kommune i Nord-Trøndelag. Et konserveringsprosjekt”. NIKU Oppdragsmelding 023, Oslo, 1996.

${ }^{68}$ Inv. no. 319, Toten Museum. SCHARFFENBERG, Katrine - Kristus fra Fjell kirke, Østre Toten: Konstruksjon, maleteknikk og behandlingshistorikk. Unpublished report, MCH 2006. 


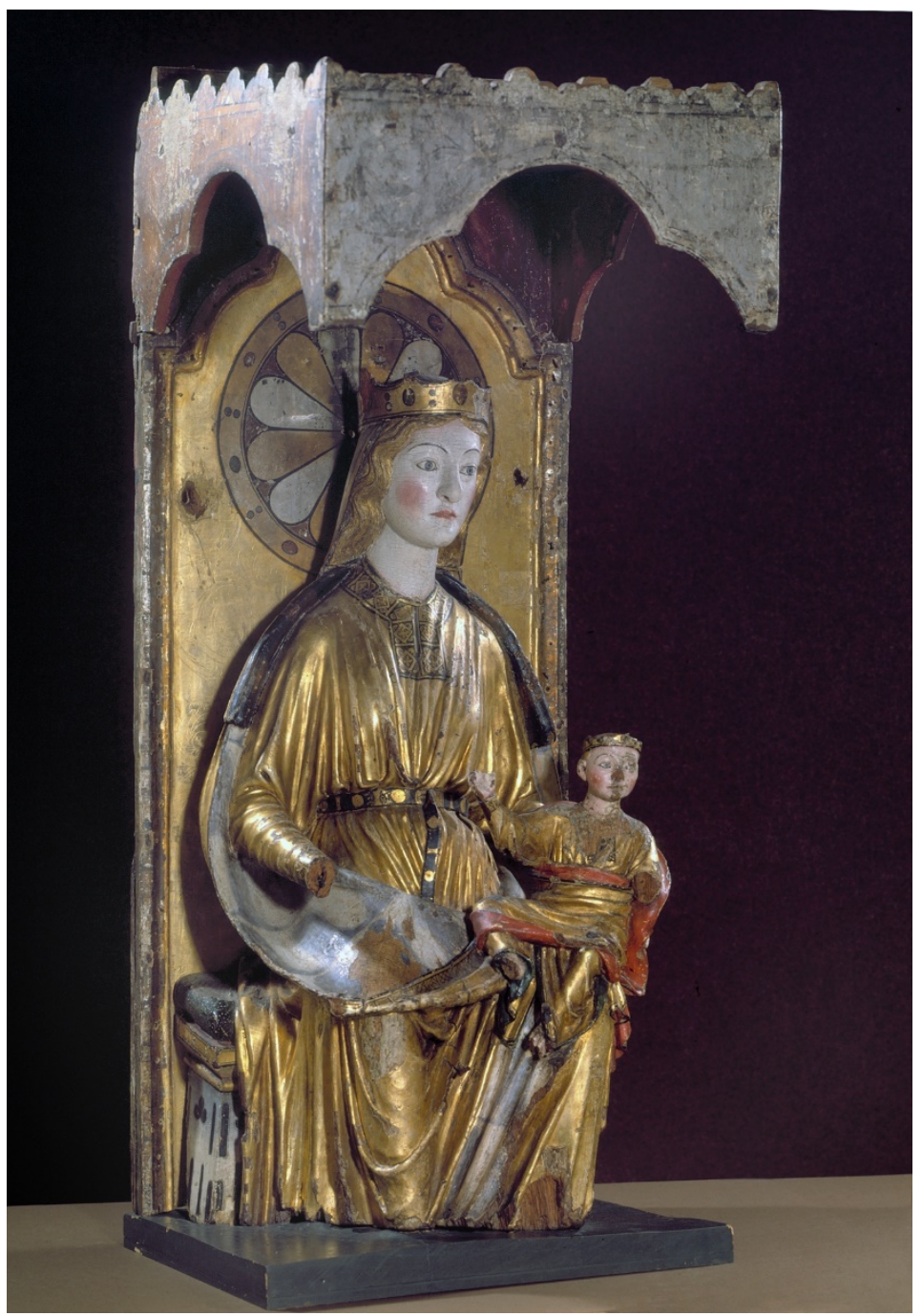

Fig. 8 - Virgin from Hove, c. 1230, Tabernacle: 124 x 52.2 x $48.7 \mathrm{~cm}$. Virgin: 94 x 45.5 x 35.5 cm. Inv. no. MA 27. (Photo (C) University museum of Bergen)

\section{Tin foil}

Parallel to the use of real gold is the glittering golden simulation: imitation gold, made by the application of a yellow organic glaze to a white metal. In the surviving $12^{\text {th }}$ century Scandinavian material, tin foil was the most common white metal used for gilding ${ }^{69}$. It was normally glazed with a yellow glaze that transformed the white metal into a golden impression, a technique named imitation gold. Tin has been identified in the loincloth of the crucifixes from Horg I, Skafså (c. 1225) ${ }^{70}$ and Grinaker (c. 1100-

\footnotetext{
${ }^{69}$ PLAHTER, Unn - "Norwegian Art Technology...”, p. 318.

${ }^{70}$ GJERTSEN, Randi - "Den korsfestede Kristus fra Skafså Kirke, Tokke Kommune i Telemark. Undersøkelser og konservering”. NIKU publikasjoner, 123, 2002, 1-34.
} 
$1150)^{71}$, on the outside of the robes of the Virgin from Urnes (fig. 4, 5) ${ }^{72}$, and as the stencil pattern and the edging of the loincloth of the crucifix from Urnes. Although tin is frequently mentioned in written sources, Anette Scholtka points out that it was seldom identified on painted works of art from the $12^{\text {th }}$ century in the material she surveyed from central Europe and Denmark ${ }^{73}$.

\section{Silver leaf}

Plahter has suggested that while silver leaf rather than tin foil was applied to art from the German speaking regions, its choice may simply have been because silver was more easily available there. Johannes Taubert describes that for the loincloth of the Forstenrieder crucifix (c. 1200-1225) "we have to imagine it as a large piece of silver cloth with a red lining held by a golden belt" and "the [gold] leaf was applied onto the completed silvering"74. Thus, it is interesting that the crucifix from Eggedal in Norway is the only late $12^{\text {th }}$-century sculpture found so far that possesses imitation gold with silver leaf on the golden crown and loincloth ${ }^{75}$. This is unlike contemporary Norwegian sculpture in Norway made with tin, and more consistent with trends in the German regions, supporting Martin Blindheim's claim that it is of a Northern continental origin rather than Norwegian ${ }^{76}$. The use of tin is also widespread in Spanish frontals from both the $12^{\text {th }}$ and $13^{\text {th }}$ centuries, and it has been identified in French sculpture ${ }^{77}$. This raises a key question: Is the use of tin in Germany rare or are the examples not yet known to us?

The technique of cast tin relief, which is known in central and southern Europe in the $12^{\text {th }}$ century, has not been observed on Scandinavian works until the $15^{\text {th }}$ century $^{78}$. There are, however, examples of a carved diaper pattern with imitation gilding, such as

\footnotetext{
${ }^{71}$ Inv. no. C 2797, MCH. BLINDHEIM, Martin - Painted Wooden Sculpture..., cat. no. 7.

${ }^{72}$ Unpublished SEM-EDX analysis by Kollandsrud, UiO 1996.

${ }^{73}$ SCHOLTKA, Annette - "Theophilus Presbyter - Die Maltechnischen Anweisungen...", p. 27.

74 TAUBERT, Johannes - Polychrome Sculpture: Meaning, Form, Conservation. MARINCOLA, Michele D. (trans.). Getty Conservation Institute: Getty Publications, 2015, 150, 154, Fig. 25.

75 Inv. no. C 10786, MCH. PLAHTER, Leif E. - "Paint Analyses of the Crucifix from Eggedal". Universitetets Oldsaksamlings årbok 1960-1961, 1963, pp. 94-108.

${ }^{76}$ BLINDHEIM, Martin - Painted Wooden Sculpture..., cat. no. 41.

${ }^{77}$ PLAHTER, Unn - Painted Altar Frontals ..., vol. 2, pp. 193-195.

${ }^{78}$ NADOLNY, Jilleen - "The Techniques and Use of Gilded Relief...".
} 
seen in the background of the relief figures in the sculpted frontal from Komnes (c. $1230-1250)^{79}$, and in the backboard of the Virgin from Vallset $^{80}$.

\section{Part gold}

Diffusion-gilded silver formed by beating a 'block' of gold attached to a much thicker 'block' of silver can be hammered down to a desired thickness. As foil metal, the gilded silver is self-supported, and when used by goldsmiths it is referred to as 'diffusiongilded silver'. When beaten into leaf metal it is no longer self-supporting and known as "Zwischgold" or "part-gold" used by the painter ${ }^{81}$. The result is somewhat paler and less expensive than a leaf of pure gold $^{82}$.

According to Jilleen Nadolny the analytical evidence currently available suggests that part-gold was first utilised by painters in the early $13^{\text {th }}$ century. Its use became more common in the $14^{\text {th }}$ century, more so on sculptures than on panel paintings ${ }^{83}$. Nadolny points to examples where part-gold was ascertained on works of art in Germany and Austria dating to the second half of the $13^{\text {th }}$ century, such as the wall paintings in the Deutschordenkirche St. Ägidien in Regensburg, on cast-relief applications of the wall paintings in the Cathedral of Gurk, and on the polychromed wood sculpture of the Enthroned Madonna and Child in Kloster Wienhausen.

The earliest Norwegian example known to the authors was identified in the hair and beard of the crucifix from Haug, Buskerud (fig. 9), dated to c. $1225^{84}$. The part gold, now blackened by corroded silver, was applied to less visible areas of the back of the

\footnotetext{
${ }^{79}$ Inv. no. C 3209, MCH. KOLLANDSRUD, Kaja; HUTH, Nadine - "Beyond the Precious..., p. 229-46.

${ }^{80}$ OLSTAD, Tone M. - "Madonna Med Barnet: konservering og restaurering av en polykrom treskulptur fra 1200-tallet i Vallset Kirke, Stange i Hedmark". NIKU oppdragsmelding 27, 1996.

${ }^{81}$ On diffusion-gilding see PLAHTER, Unn - "Norwegian Art Technology...", p. 318.

${ }^{82}$ See discussion on the prices of painting materials listed in the $15^{\text {th }}$ century Icelandic manuscript (AM $685 \mathrm{~d}$ 4to in the Arnamagnæan Institute, University of Copenhagen) in PLAHTER, Unn - Painted Altar Frontals..., vol. 2, pp. 57-60.

${ }^{83}$ NADOLNY, Jilleen - "The Techniques and Use of Gilded Relief...", p. 161.

${ }^{84}$ KOLLANDSRUD, Kaja - "Vasaris Theory of the Origins of Oil Painting and Its Influence on Cleaning Methods: The Ruined Polychromy of the Early Thirteenth Century Crucifix from Haug, Norway". in LINDLEY, Phillip (ed.) - Sculpture Conservation: Preservation or Interference?. Liverpool: Scholar Press, Ashgate Publishing Company, 1997, pp. 139-149. New SEM-EDX analysis with better resolution, performed by the authors in 2016, identified the layered structure of part gold in the blackened areas of the hair and beard, and not an alloy as first suggested in the article. The dating of the sculpture based on its construction and materiality is discussed in KOLLANDSRUD, Kaja - "Krusifiks fra Haug kirke Buskerud C nr. 3604: Undersøkelser og behandling." Varia 27, 1994, p. 26.
} 
hair and in the deepest recesses of the curly beard (fig. 10, detail of the hair of the crucifix from Haug, Buskerud). Another early Scandinavian example is the wooden Madonna from Visby (Sweden), c. 1225, which retains gilding with real gold on the front of its hair and with part-gold on the reverse ${ }^{85}$.

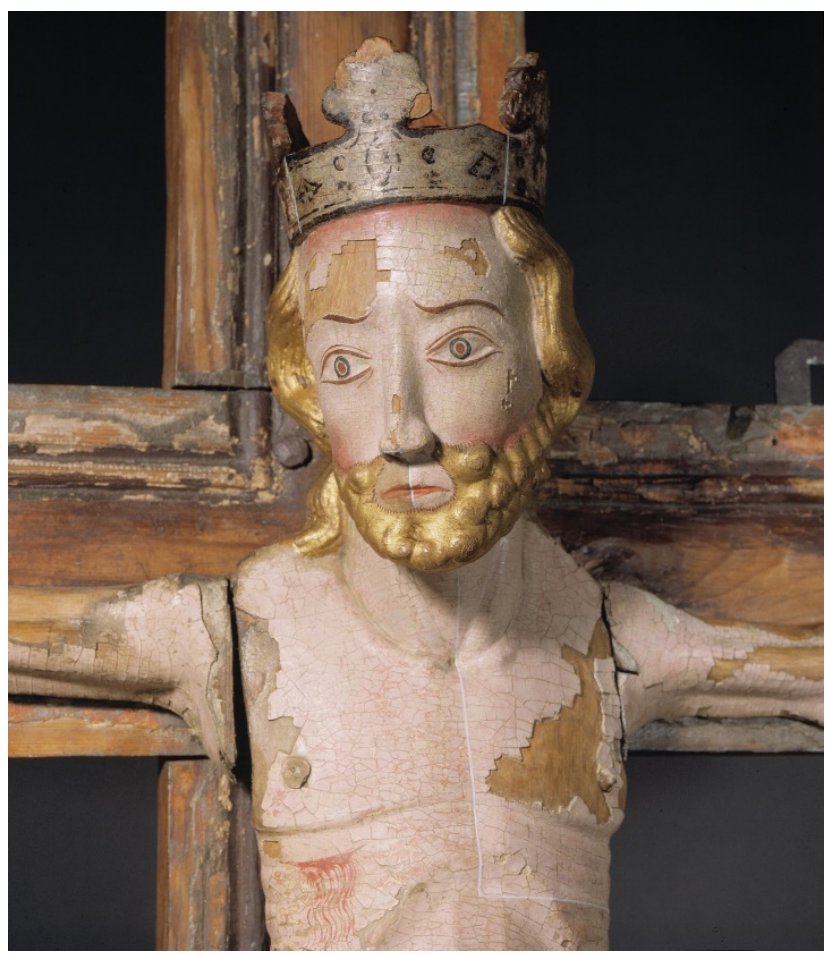

Fig. 9 - Bust detail of the crucifix from Haug. c. 1225 . Figure (alder): 109 x 92.5 x $20.0 \mathrm{~cm}$. Cross (pine): 235.5 x $146.5 \mathrm{~cm}$. Separately carved nipples; probably oak. Inv. no. C 3604, MCH. (Photo: Kaja Kollandsrud (C MCH, UiO)

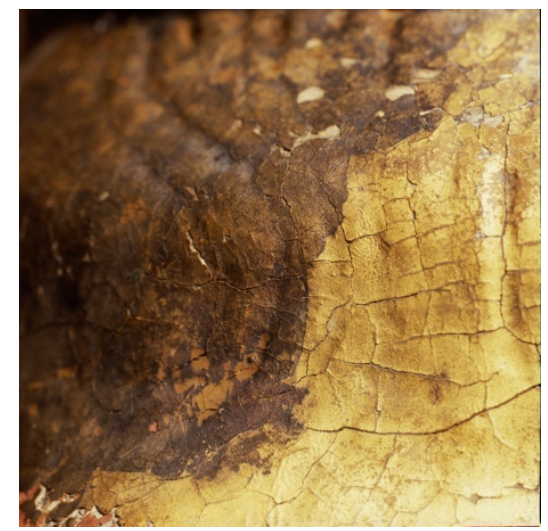

Fig. 10 - Detail of the transition between gold foil and the corroded laminate gold in the back of the hair of the crucifix from Haug. (Photo: Kaja Kollandsrud $\mathbb{C}$ MCH, UiO)

\footnotetext{
${ }^{85}$ NADOLNY, Jilleen - The Techniques and Use of Gold Relief..., p. 161.
} 


\section{The golden glaze}

The coating that changes the silvering from white to golden is described as "reddish" in hue in the Likneskjusmið. A reconstruction of the production process used to obtain pure pine resin coating, identified in the imitation gold on the Virgin from Hedalen, also results in resin with a reddish-brown colour. It was produced by dry-distillation of pinewood and collected as the first fractions before the temperature rises to levels where the non-drying tar is produced ${ }^{86}$. The fraction contains pine resin dissolved in turpentine and mixed with water. The pine resin dissolved in the turpentine was ready for application with no further refining or colouring added. It could easily be applied with a brush and dried when exposed to UV in daylight ${ }^{87}$. Likneskjusmið describes how the application of the gullfargi is performed by spreading it with the fingers over silver that has been warmed in the sun, an operation that is repeated. It is probably a resin/oil mix that is described here, as the pure pine resin cannot be applied in this way. This method is in accordance with description of a varnish or golden glaze to be spread onto a tin foil found in both Theophilus and Cennino ${ }^{88}$. GC-MS analysis performed by Raymond White, National Gallery in London, identified heat-treated pine resin as a major constituent for the yellow colouring material of the coating, and often mixed with linseed oil. In some cases, the resin was applied pure. Larch resin was identified in the frontal from Odda ${ }^{89}$.

\section{Controlling the reflexion of golden surfaces}

The differentiation of surface gloss played a major role in the medieval visual expression ${ }^{90}$. The striking effects of imitation gold due to the optical properties of the

\footnotetext{
${ }^{86}$ The tar burning was set up an led by conservator Eivind Bratlie, MCH, and performed in a traditional small-scale way with saturated roots of pine in an iron kettle packed with pine roots highly saturated with its balsam that were turned upside down onto a stone platform. It was heated by building a fire around it.

${ }^{87}$ PLAHTER, Unn - "Líkneskjusmíð...", p. 163.

${ }^{88}$ PLAHTER, Unn - “Líkneskjusmíð...”, pp. 169-171; BREPOHL, Erhard (transl.) Theophilus Presbyter Und Das Mittelalterliche Kunsthandwerk: Gesamtausgabe Der Schrift De Diversis Artibus in Zwei Bänden. Vol. 1: Malerei und Glas. Köln: Böhlau, 1999; BROECKE, Lara (transl.) - Cennino Cennini's Il Libro Dell'arte. London: Archetype Publications, 2015.

${ }^{89}$ PLAHTER, Unn - Painted Altar Frontals..., vol. 2, p. 177. Analyses was performed by WHITE, Raymond - "Analyses of Norwegian Medieval Paint Media: A Preliminary Report". in MALMANGER, Magne; BERCELLY, Laszlo and FUGLESANG, Signe (ed.) - Norwegian Medieval Altar Frontals and Related Material. Roma: Giorgio Bretschneider, 1995, pp. 127-136.

${ }^{90}$ This topic is further discussed in KOLLANDSRUD, Kaja - "The Divine Communicated through Embodied Light...".
} 
highly polished gilding and the resinous coating were a desired visual effect ${ }^{91}$. The technique gives rise to various visual appearances, such as perceived gloss, glow, binocular glitter and other complex features ${ }^{92}$. This might explain why both colourless and yellow transparent coatings were not only applied to silver, but also to gold leaf gilding to increase in the range of visual effects. A yellow glaze was applied onto the water gilding with real gold leaf on the crown and the inner dress of the Virgin from Dyste, while a transparent layer, probably a glair varnish, based on its solubility in $10 \%$ $\mathrm{KOH}$ and fluoresces blue in UV, was applied directly onto the water gilding in real gold on the Virgin's mantle. This glair varnish was also used as a coating over yellow glaze on imitation gold; i.e. the turned posts, sides of the throne, outside of the mantle and the inside of its sleeves ${ }^{93}$. As oil gilding cannot be burnished, a coating with an oil glaze will reduce light scattering and lend the matt surfaces an even deep and lustrous appearance. Such a glaze was applied to the oil gilded surfaces made with real gold leaf in the Hemse crucifix ${ }^{94}$.

Further mapping of the diverse metal gildings employed, and their geographical spread, might shed more light on the early use of glazed tin, gold, silver and part gold and their coatings. According to Tångeberg, the use of both glazed silver and part gold occur in the East until the beginning of the $15^{\text {th }}$ century ${ }^{95}$. Imitation gold is here typically found on the outside of the robes, crowns, decorative edging bands and architectural details of the shrines. This is not the case in north Germany, where such use of imitation seems to disappear in the second half of the $14^{\text {th }}$ century. Tångeberg therefore suggest that the late use of this technique can be a criterium to decide the provenance of such pieces of art. It has been suggested that the late use of imitation gold based on silver foil identified in late medieval altar shrines in Norway presents a strong argument in

91 KOLLANDSRUD, Kaja - "Polychrome Light in Medieval Norwegian Church Art $\left(12^{\text {th }}-13^{\text {th }}\right.$ Centuries)". in KROESEN, Justin E. A.; SAUERBERG, Marie Louise; NYBORG, Ebbe (ed.) - From Conservation to Interpretation: Studies in Religious Art (c. $1100-$ c. 1800) in Northern and Central Europe in Honour of Peter Tångeberg. Leuven: Peeters verlag, 2017, pp. 57-82.

${ }^{92}$ HARVEY, Joshua; KOLLANDSRUD, Kaja; SMITHSON, Hannah - "Not all that Glitters: Probing Material Perception with a Physical Imitation-gold Stimulus". Abstract for AVA Christmas Meeting, Queen Mary University of London, December 18, 2017, Perception 47, 2018.

93 SELSJORD, Marianne - "The 'Golden Madonna'...”, p. 116.

${ }^{94}$ PLAHTER, Unn - "The Crucifix from Hemse...”, pp. 14-15.

95 TÅNGEBERG, Peter - Holzskulptur und Altarschrein..., p. 236. 
connecting them to a local Norwegian origin ${ }^{96}$. A broader geographic identification of the technique, its roots and late use, should perhaps bring us closer to a better understanding of this development. More work involving reconstructions are necessary to better understand the visual effects of the various coatings and their combination when applied to the different metals used in the diverse gilding techniques.

\section{Concluding remarks}

Earlier research has established that the main trends identified in the polychrome sculpture discussed here are in line with other European findings both in terms of style and materiality. Variations in the range of painterly practices may provide indications of patterns of cultural exchange. In her exploration of the techniques of gilded relief decoration, Nadolny argues that highly useful information regarding the reasoning and motivations of the medieval craftsmen may be observed in such regional technical customs ${ }^{97}$. Further consideration of the painterly techniques seen in a broader European context is therefore highly relevant. The collection of sculpture from this early period preserved in Norway has not been fully investigated, and the potential of new scientific methods has not been completely explored.

Studies of the influence of Byzantine art in the West are frequently based on stylistic and iconographic features, found in imported objects from Byzantium. However, when Winfield in the 1960s analysed wall paintings in the East, he found that Byzantine painting technique had an impact on contemporary art in the West. Similar methods of building up colours and the rigid separation of them are used ${ }^{98}$. The same range of pigments and layered structures are recognised in $12^{\text {th }}$-century art in Norway. How western workshops adapted these techniques is uncertain, but their occurrence indicate close connections, not only among the elite, but between the craftsmen and their milieu. An enigmatic feature is the wide use of lapis lazuli in both the East and West in the $12^{\text {th }}$ century. Was its occurrence mainly linked to the Byzantine penetration into the

${ }^{96}$ KAUSLAND, Kristin - "Late Medieval Paintings in Norway - Materials, Techniques, Origins". Zeischrift für Kunsttechnologie und Konservierung 31/1, 2016, pp. 47-66.

${ }^{97}$ NADOLNY, Jilleen - The Techniques and use of Gilded Relief..., p. 100.

${ }^{98}$ WINFIELD, David C. - "Middle and later Byzantine Wall Painting...", pp. 125-126, 129. 
painter's milieu in the West? This esteemed and probably expensive pigment was probably highly available in Byzantium and Constantinople in the $12^{\text {th }}$ century and favoured by craftsmen in the East who spread their painting practices to the West. The pigment fell out of use in the West as well as the East in the $13^{\text {th }}$ century, which may have been caused by unrest in the East due to the invasion of the Mongols ${ }^{99}$.

Thus, further study of the materiality of these early objects is a potent source in the search for better understanding of the mechanisms of cultural exchange in the period. The fragmented state of sculptures preserved, due to a high number of losses over the centuries, makes the examination of the remaining surviving examples across national borders highly relevant. Mapping the choice of materials and the way they are treated and applied have, when seen in a broader European perspective, the potential to elucidate how the use of technology and techniques migrate and develop on a larger scale, geographically and through time. With more data and more precise characterisations, the patterns of change can become clearer, both when seen in a local and broader geographical setting. More evidence collected from the materials and their application can also contribute new knowledge to the many aspects of the society that produced them, on topics such as trade, development of technological and painterly expertise and their resulting visual expressions. Furthermore, questions on provenance and dating of objects can be substantiated. Changes in the availability of materials are often seen in the way the artisan chose to adapt. New research in this field will provide a better understanding of the use of diverse media and their application, as well as the various gilding techniques and their coatings within this period, both in Norway and Europe as a whole.

\section{Acknowledgements}

We want to thank Dr. Jilleen Nadolny, Art Analysis \& Research, London, Dr. Jeremy Hutchings, Norwegian Armed Forces Museum, Oslo, and professor emeritus Erla K. Hohler for their close reading and helpful suggestions to this paper.

\footnotetext{
99 PLAHTER, Unn - “The Trade in Painter's Materials...”, pp. 69-71.
} 


\section{BIBLIOGRAPHICAL REFERENCES:}

\section{Manuscripts}

BREPOHL, Erhard (trans1.) - Theophilus Presbyter und das Mittelalterliche Kunsthandwerk: Gesamtausgabe der Schrift De Diversis Artibus in Zwei Bänden. Vol. 1: Malerei und Glas. Köln: Böhlau, 1999.

BROECKE, Lara (trans1.) - Cennino Cennini's Il Libro Dell'arte. London: Archetype Publications, 2015.

MS AM $194.8^{\circ}$ in the Arnamagnæan Institute, University of Copenhagen.

MS AM 685 d 4to in the Arnamagnæan Institute, University of Copenhagen.

\section{Printed sources}

BLINDHEIM, Martin - "Scandinavian Art and Its Relations to European Art around 1200". in The Year 1200: A Symposium. New York: The Metropolitan Museum of Art, 1975, pp. 429-468.

BLINDHEIM, Martin - Painted Wooden Sculpture in Norway c. 1100-1250, Medieval Art in Norway. Oslo: Scandinavian University Press, 1998.

BLINDHEIM, Martin - Gothic Painted Wooden Sculpture in Norway 1220-1350. Oslo: Messel forlag, 2004.

BOSSELMANN-RUICKBIE, Antje - "Contact between Byzantium and the West from the $9^{\text {th }}$ to the $15^{\text {th }}$ Century: Reflections in Goldsmiths' Works and Enamels." in DAIM, Falko; HEHER, Dominik; RAPP, Claudia (ed.) - Menschen, Bilder, Sprache, Dinge Wege der Kommunikation zwischen Byzanz und dem Westen 1: Bilder und Dinge. Studien zur Ausstellung 'Byzanz \& der Westen. 1000 vergessene Jahre'. Mainz: Verlag des Römisch-Germanischen Zentralmuseums, 2018, pp. 73-104. 
BRACHERT, Thomas - "Fassung von Bildwerken: Geschichte". in Reallexicon zur deutschen Kunstgeschichte, vol. 7. München: Beck, 1981, pp. 793-798.

BYNUM, Caroline Walker - Christian Materiality: An Essay on Religion in Late Medieval Europe. New York: Zone Books, 2011.

EKROLL, Øystein - "Erkebiskop Eystein, Oktogonen i Kristkyrkja og Kristi Gravkyrkja i Jerusalem”. in BJØRLYKKE, Kristin et alii (ed.) - Eystein ErlendssonErkebiskop, politiker og kirkebygger. Trondheim: Nidaros domkirkes restaureringsarbeiders forlag, 2012.

ELKINS, James - "On Some Limits of Materiality in Art History,” in NEUNER, Stefan; GELSHORN, Julia (ed.) - Taktilität: Sinneserfahrung als Grenzerfahrung. Das Magazin des Instituts für Theorie 12, 2008, pp. 25-30.

ENDEMANN, Klaus - “Zur Holzskulptur Des Frühen Mittelalters. Voraussetzungen und Funktion - Schnitztechnik und Fassung”, Zeitschrift für Kunsttechnologie und Konservierung 26/1, 2012, pp. 400-434.

FRØYSAKER, Tine - "Den middelalderske Kristusfiguren fra Otterøy kirke, Namsos kommune i Nord-Trøndelag. Et konserveringsprosjekt”. NIKU Oppdragsmelding 023, Oslo, 1996.

FRØYSAKER, Tine; KOLLANDSRUD, Kaja - "The Calvary Group in Urnes Stave Church, Norway: A Technological Examination". in NADOLNY, Jilleen (ed.) Medieval Painting in Northern Europe: Techniques, Analysis, Art History. London: Archetype, 2006, pp. 43-58.

GARIPZANOV, Ildar - "Wandering Clerics and Mixed Rituals in the Early Christian North, c. 1000-1150". The Journal of Ecclesiastical History 63/1, 2012, pp. 1-17.

GJERTSEN, Randi - "Den korsfestede Kristus fra Skafså Kirke, Tokke Kommune i Telemark. Undersøkelser og konservering”. NIKU publikasjoner 123, 2002, pp. 1-34. 
HAASTRUP, Ulla - "Byzantisk klædte ærkeengle i danske fresker: Kombinationen af ærkeengle med Majestas Domini i 1. halvdel af 1100-tallet", Nordic Review of Iconography 1, 2014, pp. 6-36.

HALLDÓRSSON, Ólafur - “Líkneskjusmið”, Árbók hins islenzka fornleifafélags 1973, 1974, pp. 5-17.

HARVEY, Joshua; KOLLANDSRUD, Kaja; SMITHSON, Hannah - "Not all that Glitters: Probing Material Perception with a Physical Imitation-gold Stimulus", AVA Christmas Meeting, Queen Mary University of London, December 18, 2017, Perception 47, 2018.

HOHLER, Erla B.; MORGAN, Nigel J.; WICHSTRØM, Anne - Painted Altar Frontals of Norway, 1250-1350. vol. 1: Artists, Styles and Iconographye. London: Archetype Publications, 2004.

JÄGER, Elisabeth - “Zur Polychromie der Kölner Skulptur vom 12.- Bis zum Ende des 14. Jahrhunderts". in BERGMANN, U. (ed.) - Schnütgen-Museum. Holzskulpturen des Mittelalters, (1000-1400). Köln: Schnütgen-Museum, 1989, pp. 99-104.

KALAND, Bjørn - "Baldakin Fra Hopperstad - Madonna Fra Hove", Foreningen til norske fortidsminnesmerkers bevaring LIX. Oslo: Foreningen til norske fortidsminnesmerkers bevaring, 1973, pp. 1-14.

KARGÈRE, Lucretia; RIZZO, Adriana - "Twelfth-Century French polychrome sculpture in The Metropolitan Museum of Art: Materials and Techniques". Metropolitan Museum Studies in Art, Science, and Technology 1, 2010, pp. 39-72.

KAUSLAND, Kristin - "Late Medieval Paintings in Norway - Materials, Techniques, Origins". Zeischrift für Kunsttechnologie und Konservierung 31/1, 2016, pp. 47-66.

KITZINGER, Ernst - "The Byzantine Contribution to Western Art of the Twelfth and Thirteenth Centuries". Dumbarton Oaks Papers 20, 1966. 
KLOCKE, Jens; LEHMANN, Jirina - "Technik des Unterlegens von grobkörnigen Pigmenten: die Veneda des Theophilus". Restauro 107/5, 2001, pp. 373-375.

KOLLANDSRUD, Kaja - "Krusifiks fra Haug kirke Buskerud C nr. 3604: Undersøkelser og behandling." Varia 27, 1994.

KOLLANDSRUD, Kaja - "Vasaris Theory of the Origins of Oil Painting and Its Influence on Cleaning Methods: The Ruined Polychromy of the Early Thirteenth Century Crucifix from Haug, Norway”. in LINDLEY, Phillip (ed.) - Sculpture Conservation: Preservation or Interference?, Liverpool: Scholar Press, Ashgate Publishing Company, 1997, pp. 139-149.

KOLLANDSRUD, Kaja - "Technological Mapping of Norwegian Polychrome Wooden Sculpture, 1100-1350: a Preliminary Overview". in HOFSETH, Ellen H. (ed.) UKM skrifter 1. Oslo: Universitetets kulturhistoriske museer, 2002, pp. 125-141.

KOLLANDSRUD, Kaja - “340 Kruzifix aus Lunder”. in KROKER, Martin (ed.) Credo. Christianisierung Europas im Mittelalter. Katalog Band II, VI Sterbende götter: Christianisierung Skandinaviens. Petersberg: Michael Imhof Verlag, 2013, pp. 340-341.

KOLLANDSRUD, Kaja - "Polychrome Light in Medieval Norwegian Church Art $\left(12^{\text {th }}-13^{\text {th }}\right.$ Centuries)". in KROESEN, Justin E. A.; SAUERBERG, Marie Louise; NYBORG, Ebbe (ed.) - From Conservation to Interpretation: Studies in Religious Art (c. 1100-c. 1800) in Northern and Central Europe in Honour of Peter Tångeberg. Leuven: Peeters verlag, 2017, pp. 57-82.

KOLLANDSRUD, Kaja - Evoking the Divine: The Visual Vocabulary of Sacred Polychrome Wooden Sculpture in Norway between 1100 and 1350. Oslo: University of Oslo, 2018. Unpublished PhD thesis.

KOLLANDSRUD, Kaja - "Between Heaven and Earth". in BJERREGAARD, Peter (ed.) - Transformation: Faith and Sacred Objects in the Middle Ages. Trondheim: Museumsforlaget AS, 2018, pp. 68-71. 
KOLLANDSRUD, Kaja - "The Divine Communicated through Embodied Light in Medieval Sculpture in Norway". Selected papers from the conference Science, Imagination, Wonder: Robert Grosseteste and his Legacy. Pembroke College, Oxford University, 3-5. April 2018. Brepols; due 2019.

KOLLANDSRUD, Kaja; HUTH, Nadine - "Beyond the Precious with Painterly Effects: The Thirteenth Century Sculpted Frontal from Komnes, Buskerud in Norway". in GRINDER-HANSEN, Poul (ed.) - Image and Altar 800-1300. Papers from an International Conference in Copenhagen 24-27 October. Copenhagen: PNM Publications from the National Museum Studies in Archaeology \& History 2014, pp. 229-246.

KUMLER, Aden; LAKEY, Christopher R. - "Res Et Significatio: The Material Sense of Things in the Middle Ages". Gesta 51, 2012, pp. 1-17.

LAMARK, Wenche G. H. - Tanum Kirkes Kalkmalerier. University of Oslo: Department of Art History, 2009. Master thesis.

LINDBERG, Håkan - "Some Notes Regarding the Conservation of the Viklau Madonna (Gotland, Sweden)". in KROESEN, Justin E. A.; SAUERBERG, Marie Louise; NYBORG, Ebbe (ed.) - From Conservation to Interpretation: Studies in Religious Art (c. $1100-$ c. 1800) in Northern and Central Europe in Honour of Peter Tångeberg, Art and Religion 7, Peeters verlag, 2017, pp. 11-22.

MERCIER, Emmanuelle; SANYOVA, Jana - "Art et techniques de la polychromie romane sur bois dans dans l'Europe du Nord". in Les Cahiers de Saint-Michel de Cuxa XLIII, pp. 125-135.

MORGAN, Nigel J. - “4 Dating, Styles and Groupings". in HOHLER, Erla B.; MORGAN, Nigel J.; WICHSTRØM, Anne - Painted Altar Frontals of Norway, 12501350. Vol. 1: Artists, Styles and Iconographye. London: Archetype Publications, 2004, pp. 20-38. 
NADOLNY, Jilleen - "Some Observations on Northern European Metalbeaters and Metal Leaf in the Late Middle Ages". in RUSHFIELD, Anne; BALLARD, Mary W. Studies in the Honour of Lawrence J. Majewski on the Occasion of His $80^{\text {th }}$ Birthday, February $10^{\text {th }} 1999$. New York: Conservation Center of the Institute of Fine Arts, 1999, pp. 134-160.

NADOLNY, Jilleen - The Techniques and use of Gilded Relief Decoration by Northern European Painters, c. 1200-1500. London: University of London, 2001. Unpublished $\mathrm{PhD}$ thesis.

NADOLNY, Jilleen - “All That is Burnished isn't Bole. Reflections on Medieval Water Gilding: Part 1: Early Medieval to 1300". in NADOLNY, Jilleen (ed.) - Medieval Painting in Northern Europe. Techniques, Analysis, Art History. London: Archetype, 2006, pp. 148-162.

NADOLNY, Jilleen - "One Craft, many Names: Gilders, Preparers, and Polychrome Painters in the $15^{\text {th }}$ and $16^{\text {th }}$ Centuries." in Art Technical Source Research. ICOM-CC, 2008, pp. 10-17.

OLSTAD, Tone M. - "Madonna med barnet: konservering og restaurering av en polykrom treskulptur fra 1200-tallet i Vallset Kirke, Stange i Hedmark", NIKU oppdragsmelding 27 (1996).

PENTCHEVA, Bissera V. - The Sensual Icon: Space, Ritual, and the Sences in Byzantium. Pennsylvania: The Pennsylvania State University Press, 2010.

PERCH-NIELSEN, Katharina von Salis; PLAHTER, Unn - "Analyses of Fossil Coccoliths in Chalk Grounds of Medieval Art in Norway". in MALMANGER, Magne; BERCELLY, Lazlo; FUGLESANG, Signe (ed.) - Norwegian Medieval Frontals. Acta ad archaeologiam et artivm historiam pertinentia XI. Papers from the Conference in Oslo December 1989. Roma: Giorgia Bretschneider, 1995, pp. 145-156. 
PILZ, Elisabeth (ed.) - Byzantium and Islam in Scandinavia. Studies in Mediterranean Archaeology, vol. CXXVI. Jonsered: Paul Åströms förlag, 1998.

PLAHTER, Leif E. - "Paint Analyses of the Crucifix from Eggedal”. Universitetets Oldsaksamlings årbok 1960-1961, 1963, pp. 94-108.

PLAHTER, Unn - "Noen observasjoner i 1100-tallets bemaling sett i relasjon til antemensalemaleriet". Paper presented at the Nordisk konservatorforbund's 9. kongress, Oslo, 1981, pp. 71-78.

PLAHTER, Unn - "Líkneskjusmíð: 14 $4^{\text {th }}$-Century Instructions for Painting from Iceland”. in MALMANGER, Magne; BERCELLY, Laszlo; FUGLESANG, Signe (ed.) - Norwegian Medieval Altar Frontals and Related Material. Roma: Giorgio Bretschneider, 1995, pp. 157-72.

PLAHTER, Unn - “A Survey of Pigments and Pigment application on 31 Norwegian Medieval Oil Paintings from the period 1250-1350". in VONTOBEL, R. (ed.) Preprints of the ICOM-CC $13^{\text {th }}$ Triannial Meeting, Rio de Janeiro, 22-27. September. London: James and James Science Publishers Ltd., 2002, vol. 1, pp. 446-454.

PLAHTER, Unn - Painted Altar Frontals of Norway, 1250-1350. Vol. 2: Materials and Technique. London: Archetype Publications, 2004.

PLAHTER, Unn - "The Crucifix from Hemse: Analyses of the Painting Technique". in NADOLNY, Jilleen (ed.) - Medieval Painting in Northern Europe. Techniques, Analysis, Art History. London: Archetype, 2006 (First printed 1984), pp. 11-20.

PLAHTER, Unn - "Medieval Painting Materials and Techniques in Norway. To what extent did the Painters tempt to Simulate Goldsmith's Work?", Zeitschrift für Kunsttechnologie und Konservierung 24/1, 2010, pp. 160-169.

PLAHTER, Unn - "The Trade in Painter's Materials in Norway in the Middle Ages. Part 2: Materials, Technique and Trade from the Twelfth Century to the Mid-Fourteenth 
Century”. in KIRBY, Jo; NASH, Susie; CANNON, Joanna (ed.) - Trade in Artist's Materials. Markets and Commerce in Europe to 1700. London: Archetype publisher, 2010, pp. 64-73.

PLAHTER, Unn - "Norwegian Art Technology in the Twelfth and Thirteenth Centuries: Materials and Techniques in a European Context". Zeitschrift für Kunsttechnologie und Konservierung 28/1 (2014), pp. 298-332.

RICE, David Talbot - "The Britain and the Byzantine World in the Middle Ages". in VOLBACH, Wolfgang Fritz (ed.) - Byzantine Art - A European Art. Lectures. Athen: Department of Antiquities and Archaeological Restoration, 1966, pp. 21-42.

SCHARFFENBERG, Katrine - Kristus fra Fjell kirke, Østre Toten: Konstruksjon, maleteknikk og behandlingshistorikk. Unpublished treatment report, MCH 2006.

SCHOLTKA, Annette - "Theophilus Presbyter - Die Maltechnischen Anweisungen und Ihre Gegenüberstellung mit Naturwissenschaftlichen Untersuchungsbefunden”. Zeitschrift für Kunsttechnologie und Konservierung, 6/1, 1992, pp. 44-45.

SELSJORD, Marianne - “The 'Golden Madonna' from Dyste Church”. In Yearbook of the Historical Archives of Historical Art Technology. Technologia Artis. Prague: The Union of Czech Artists in collaboration with the Institute for Art history ${ }^{\wedge} \mathrm{CSAV}$ and the Academy of Fine Arts in Prague, 1993, pp. 113-116.

SERCK-DEWAIDE, Myriam - "The History and conservation of the surface coating on European gilded-wood Objects”. in BIGELOW, D.; CORNU, E.; LANDREY, G. J.; VAN HORNE, C. (ed.) - Gilded Wood, Conservation and History. Sound View Press, Madison (CT), 1991, pp. 65-73.

TAUBERT, Johannes - Polychrome Sculpture: Meaning, Form, Conservation. MARINCOLA, Michele D. (trans.). Getty Conservation Institute: Getty Publications, 2015 . 
TÅNGEBERG, Peter - Holzskulptur Und Altarschrein. Studien Zu Form, Material Und Technik Mittelalterliche Plastik in Schweden. München: Georg D. W. Callwey, 1989.

TÅNGEBERG, Peter - "The Crucifix from Hemse: Analyses of the Painting Technique”. in NADOLNY, Jilleen (ed.) - Medieval Painting in Northern Europe. Techniques, Analysis, Art History. London: Archetype, 2006 (First printed 1984), pp. 110.

URBANEK, Regina - "Die Hovener Madonna - Bestand und Bewertung”, Zeitschrift für Kunsttechnologie und Konservierung 30/2, 2016, pp. 261-228.

WHITE, Raymond - "Analyses of Norwegian Medieval Paint Media: A Preliminary Report". in MALMANGER, Magne, BERCELLY, Laszlo and FUGLESANG, Signe (ed.) - Norwegian Medieval Altar Frontals and Related Material. Roma: Giorgio Bretschneider, 1995, pp. 127-136.

WIIK, Svein - "Líkneskjusmíð. Medieval Polychrome Technique in Iceland". Zeitschrift für Kunsttechnologie und Konservierung 9, 1995, pp. 327-336.

WILLIAMSON, Beth - "Material Culture and Medieval Christianity". in ARNOLD, John H. (ed.) - The Oxford Handbook of Medieval Christianity. Oxford, 2014.

WILLIAMSSON, Paul - Gothic Sculpture 1140-1300, Pelican History of Art. New Haven and London: Yale University Press, 1995.

WINFIELD, David C. - "Middle and later Byzantine Wall Painting Methods. A Comparative Study". Dumbarton oaks Papers. Washington: Dumbarton Oaks Centre for Byzantine Studies, Trustees for Harvard University, 1968. 


\section{COMO CITAR ESTE ARTIGO}

\section{Referência electrónica:}

KOLLANDSRUD, Kaja; PLAHTER, Unn - "Twelfth and early thirteenth century polychromy at the northernmost edge of Europe: past analyses and future research". Medievalista 26 (Julho-Dezembro 2019). [Em linha] [Consultado dd.mm.aaaa]. Disponível em http://www2.fcsh.unl.pt/iem/medievalista/MEDIEVALISTA26/ Kollandsrud-plahter2605.html ISSN 1646-740X.

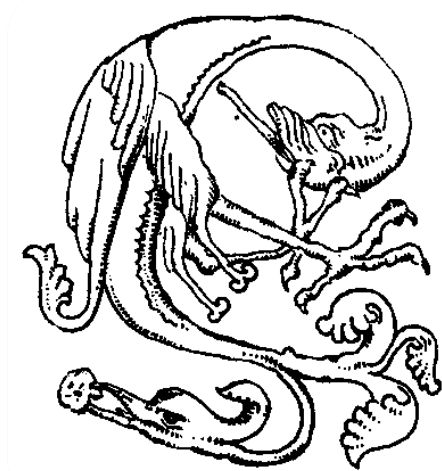

